\title{
Hedge fund politics and portfolios
}

\author{
November 7, 2016 \\ Luke DeVault \\ and \\ Richard Sias*
}

\begin{abstract}
Consistent with the well-documented relation between political orientation and psychological traits, hedge funds' political orientations are related to their portfolio decisions. Relative to politically conservative hedge funds, politically liberal hedge funds exhibit a preference for smaller stocks, less mature companies, volatile stocks, unprofitable companies, non-dividend paying companies, and lottery-type securities. Politically liberal hedge funds are also more likely to enter new positions or fully exit existing positions, and make larger adjustments to their U.S. equity market exposure. Our results suggest that psychological characteristics can influence the portfolio decisions of even those at the very top of the financial sophistication ladder.
\end{abstract}

JEL classification: G11; G23

Keywords: Psychology; Political orientation; Hedge funds; Portfolio decisions

\footnotetext{
* DeVault is from the Department of Finance, Clemson University, Clemson, South Carolina, 29634; ldevaul@clemson.edu. Corresponding Author: Sias is from Department of Finance, Eller College of Management, University of Arizona, Tucson, Arizona 85721, (520)621-3462, sias@eller.arizona.edu.
} 


\section{Hedge Fund Politics and Portfolios}

\section{Introduction}

Although it is well known that both institutional and individual investors' equity portfolios exhibit substantial heterogeneity, we have little understanding of what drives these differences.1 One promising stream of research suggests that psychological characteristics—related to genetics or life experience-can help explain cross-sectional variation in portfolio and security selection decisions. Because research suggests that the role of psychological factors in financial decision making declines with investor sophistication, it is not surprising that most of the evidence linking psychological characteristics and investors' decisions is limited to relatively unsophisticated individual investors.2 Nonetheless, a few recent studies suggest that psychological characteristics influence the decisions of some mutual funds and smaller, presumably less sophisticated, institutional investors. As Shu, Sulaeman, and Yeung (2012) point out in their examination of religious beliefs and mutual fund behavior, the link between professional money management and psychological characteristics is surprising because the competitiveness of the money management industry means that professional investors have a strong incentive to focus on performance maximizing strategies and such strategies should be invariant to managers' psychological characteristics.

It is well recognized, of course, that even if psychological characteristics influence the trading decisions of some investor groups, the asset pricing implications will be negligible as long as there is a sufficiently funded group of investors willing to exploit those whose decisions are influenced by non-performance related factors (e.g., Friedman (1953), Fama (1965)). Because hedge funds are widely viewed as the most sophisticated investor class, they are the most likely candidate for this role. 3

1 See, for example, Cesarini, Johannesson, Lichenstein, Sandewall, and Wallace (2010), Campbell (2006), and Curcuru, Heaton, Lucas, and Moore (2009) for additional discussion.

2 We review this literature in the next section.

3 It appears widely accepted that hedge funds are viewed as the most sophisticated investor group. For instance, Stein (2009) points out that, "Hedge funds are commonly thought of as the prototypical sophisticated investors..." Similarly, 
Consistent with this view, a number of recent studies suggest that hedge funds are better informed than other institutional investors (e.g., Sias, Turtle, and Zykaj (2016), Cao, Chen, Goetzmann, and Liang (2015), Cao, Liang, Lo, and Petrasek (2015))

In addition, the incentives for maximizing performance are stronger for hedge funds than other institutions for at least two reasons. First, unlike most other institutional investors, hedge funds have performance-related incentive fees (historically $20 \%$ of profits). Second, hedge funds have the most sophisticated investor base-primarily consisting of pension funds, foundations, and very wealthy individuals.4 Getmansky, Lo, and Makarov (2004) summarize the view of hedge funds and market efficiency captured in the literature, "And if this self-correcting mechanism of the Efficient Markets Hypothesis is at work among any group of investors in the financial community, it surely must be at work among hedge-fund managers, which consists of a highly trained, highly motivated, and highly competitive group of sophisticated investment professionals."

This study investigates whether psychological characteristics impact hedge funds' security selection and portfolio decisions. The question is important for at least three reasons. First, hedge funds have grown to become an important force in equity markets, accounting for $10 \%$ of the average stock's ownership and one-third of NYSE trading volume (Cao, Liang, Lo, and Petrasek (2015)). Second, as noted above, an extensive literature suggests that the effect of psychological characteristics declines with investor sophistication. Although there is nascent evidence that the investment decisions of some institutional investors (mutual funds and smaller institutional investors) are influenced by

Brunnermeier and Nagel (2005) claim, "Hedge funds are among the most sophisticated investors—probably closer to the ideal of 'rational arbitrageurs' than any other class of investors."

4 A broad literature argues that hedge funds have the most sophisticated client base. For instance, Baquero, ter Horst, and Verbeek (2005) note that hedge fund clients are limited to qualified investors who, “...have sophisticated understanding of financial markets..." and pension funds with at least $\$ 25$ million in assets. Similarly, Brav, Jiang, Partnoy, and Thomas (2008) note that, "...hedge funds avoid the Investment Company Act of 1940 by having a relatively small number of sophisticated investors.” Further, Akbas, Armstrong, Sorescu, and Subrahmanyam (2015) use flows to hedge funds as a measure of 'smart money' and find that smart money appears to attenuate mispricing while dumb money (flows to mutual funds) magnify mispricings. 
psychological characteristics, there is effectively no evidence of a systematic relation between hedge funds' decisions and psychological characteristics. 5 Given hedge funds are viewed as the most sophisticated investor class, our tests examine whether the impact of psychological characteristics runs to the very top of the financial sophistication ladder. Third, evidence that hedge fund managers' decisions are influenced by psychological characteristics implies that we cannot be assured that even the most sophisticated investors are immune to these influences and will therefore correct mispricing caused by other, less sophisticated, investors.

Following several recent studies, we use individuals' political orientations (as revealed through their political contributions) as an instrument for their psychological characteristics to test if sophisticated investors' psychological characteristics influence their security selection and portfolio decisions. Specifically, more than 60 years of psychology and political science research demonstrates that political ideology is strongly related to psychological characteristics - relative to conservatives, liberals are more tolerant of ambiguity and uncertainty, more open to new experiences, have lower levels of fear, exhibit higher integrative complexity, and have lower needs for order, structure, and closure (e.g., Jost, Glaser, Kruglanski, and Sulloway (2003)). Moreover, these psychological characteristics are strongly related to political ideology not only through environment (or nurture), but also through genetics (or nature), e.g., evidence reveals that both brain structure and brain processing differ between conservatives and liberals.

Given the well documented relation between political ideology and psychological characteristics, we hypothesize that politically conservative hedge funds' long equity portfolios will, on average, exhibit less weight in securities with the most subjective valuations. Specifically, we focus on six security characteristics identified in previous work-the five characteristics identified by Baker

5 Hong and Kostovetsky (2012) examine mutual funds' political donations and portfolio political characteristics (e.g., holdings in politically sensitive industries such as tobacco). They also include a small sample of hedge funds in their study (see their Table 8). We discuss differences between their study, other related papers, and our study in the next section. 
and Wurgler ((2006) p. 1648) that capture the "subjectivity of their valuation" and lottery-type securities as identified by Kumar, Page, and Spalt (2011). Further, we hypothesize that politically liberal hedge funds, relative to politically conservative hedge funds, will exhibit greater portfolio turnover, greater willingness to enter new securities, greater willingness to completely exit existing positions, and greater willingness to adjust their exposure to U.S. equity markets.

By construction, we focus on portfolio and security characteristics with no direct link to politics.6 That is, we do not claim political orientation is the source of causality. Rather, based on a wellestablished psychology and political science literature, political orientation is the instrument we use to identify the nature of hedge fund managers' psychological characteristics. Figure 1 captures the framework for our research question. Specifically, we hypothesize that psychological characteristics (which are a function of both nature and nurture) influence both political orientation and portfolio decisions and, as a result, hedge fund managers' political orientations are related to their security selection and portfolio decisions.7

\section{[Insert Figure 1 about here]}

Our empirical tests provide the first systematic evidence that hedge fund managers' psychological characteristics influence their security selection and portfolio characteristics. On average, politically liberal hedge funds' long-equity portfolios contain a greater weight in more speculative stocks—-smaller stocks, younger companies, more volatile stocks, unprofitable companies, non-dividend paying companies, and lottery-type stocks—relative to their politically conservative counterparts. Politically liberal hedge funds, on average, are also more likely to completely liquidate

6 For example, we do not examine corporate social responsibility or exposure to "sin" stocks.

7 Recent studies use this same framework to examine the relation between corporate managers' political donations and corporate decisions (Hutton, Jiang, and Kumar (2014)) or equity analysts' political donations and their forecasts (Jiang, Kumar, and Law (2016)). 
an equity position or enter a new equity position and exhibit a greater willingness to adjust their exposure to U.S. equity markets.

The relation between political orientation and portfolio characteristics is both statistically and economically meaningful—for our broadest tests, the effect size ranges from $12 \%$ to $24 \%$ of the standard deviation of the cross-sectional variation across hedge fund portfolios. For instance, the value-weighted mean market capitalization of securities held by politically liberal hedge funds averages 0.22 standard deviations smaller than value-weighted mean market capitalization of securities held by politically conservative hedge funds. Moreover, the evidence is stronger when more clearly isolating the variation in portfolio preferences related to psychological characteristics by using stricter definitions of political conservatism, controlling for fund characteristics (e.g., fund age), controlling for manager characteristics (e.g., manager age), or controlling for both manager and fund characteristics simultaneously. Additional tests reveal no evidence that the relation between hedge funds' political orientations and their security selection and portfolio decisions is related to hedge funds attempting to "buy" performance via political contributions.

Our results may appear surprising given the view that hedge funds use sophisticated valuation models. Nonetheless, recent work demonstrates that hedge funds' long equity portfolios exhibit a tremendous amount of cross-sectional heterogeneity. Sias, Turtle, and Zykaj (2016) report, for example, that more than $95 \%$ of hedge fund pairs have less than $10 \%$ overlap in their long equity portfolios. Our results suggest that psychological factors can help explain this cross-sectional variation in hedge funds managers' security selection and portfolio decisions.

In sum, our goal is straightforward: testing whether the investor group at the top of the financial sophistication ladder-those investors who are expected to systematically correct mispricing due to less-sophisticated investors' non-performance maximizing trades-are immune to the influence of psychological characteristics. As pointed out by Cesarini, Johannesson, Lichtenstein, 
Sandewall, and Wallace (2010), the relation between psychological characteristics and portfolio decisions may reflect how psychological characteristics influence risk preferences, views of expected returns, or behavioral biases. Moreover, psychological characteristics may impact decisions as a result of both risk aversion and ambiguity aversion.s Following these authors, we do not hypothesize about the specific mechanism(s) that cause psychological characteristics to influence decisions (e.g., differences in risk aversion versus differences in behavioral biases). Rather we focus on testing if there is evidence that psychological characteristics influence the decisions of even the most sophisticated investor group.

\section{Background}

\subsection{Political ideology and psychological characteristics}

There is voluminous evidence dating back at least 65 years (e.g., Adorno, Frenkel-Brunswik, Levinson, and Sanford (1950)) of a robust relation between psychological characteristics and political attitudes. For example, in a meta-analysis of 88 samples in 12 countries with over 22,800 cases, Jost, Glaser, Kruglanski, and Sulloway (2003) find strong evidence (i.e., all relations are statistically significant at the $1 \%$ level) that politically conservative individuals are less tolerant of ambiguity, exhibit lower integrative complexity, are less open to new experiences, avoid uncertainty, and exhibit a stronger need for order, structure, and closure. Consistent with this evidence, research (e.g., Kam and Simas (2010)) also demonstrates that individuals' tolerance for risk is strongly related to political ideology in that liberals are willing to accept greater risk than conservatives. 9

8 Risk aversion refers to situations with known probabilities (e.g., an urn contains 50 red balls and 50 blue balls) whereas ambiguity aversion refers to situations with unknown probabilities (e.g., an urn contains 100 balls, but one does not know the number of red or blue balls).

9 Kam and Simas (2010) create a risk acceptance index based on a battery of questions - some of which are financiallyoriented. For example, the authors ask "Suppose you were betting on horses and were a big winner in the third or fourth race. Would you be more likely to continue playing or take your winnings? (Definitely continue playing; Probably continue playing; Not sure; Probably take my winnings; Definitely take my winnings). Other questions, however, focus on nonfinancial risk, e.g., based on a seven point scale, subjects indicate their relative agreement with the following two statements, "You should be cautious about making major changes in your life" versus "You will never achieve much in life unless you act boldly." 
A large body of political science research also demonstrates that Republicans are much more likely than Democrats to be conservative and Democrats are more likely than Republicans to be liberal. For example, a liberal-conservative scale is much more important than age, education, income, gender, marital status, union membership, and religion in predicting party membership (e.g., Abramowitz and Saunders (2006)).10 Jost (2006) reports that respondents' self-placement on an ideological liberalconservative scale explains “...85\% of the statistical variation in self-reported voting behavior over the last 32 years." Moreover, both the polarization between conservatives and liberals and the relation between political ideology and party membership have dramatically increased since the 1970s (see Abramowitz and Saunders (2006, 2008)).

Traditionally, environmental factors have been assumed to drive political ideology (e.g., Campbell, Converse, Miller, and Stokes (1960)). For instance, parents, families, teachers, and peers all contribute to an individual's political orientation (e.g., Settle, Bond, and Levitt (2011)). A number of studies in the past decade, however, provide evidence that political orientation is as much nature as nurture, i.e., political orientation, at least in part, is literally in our DNA. For instance, evidence (e.g., Alford, Funk, and Hibbing (2005), Settle, Dawes, and Fowler (2009)) demonstrates that identical twins (who share $100 \%$ of their DNA) exhibit more similar political beliefs than fraternal twins (who, on average, share $50 \%$ of their DNA). Moreover, evidence indicates liberals and conservatives differ in brain structure. For example, Kanai et al. (2011) find (via MRI brain scans) that subjects identifying themselves as conservatives had larger right amygdalae (the part of the brain associated with emotional processing including fear processing) and subjects identifying themselves as liberals had larger anterior cingulate cortex (the part of the brain associated with monitoring uncertainty and conflict). The authors successfully classify more than $70 \%$ of participants as liberal or conservative based solely on

10 Jiang, Kumar, and Law (2016) provide additional discussion of the evidence linking party identification and political conservatism/liberalism. 
grey matter volume of these two brain regions. Other studies (e.g., Amodio, Jost, Master, and Yee, (2007), Schreiber et al. (2013), and Ahn et al. (2014)) find meaningful differences in the manner in which conservatives' and liberals' brains function. Moreover, recent advances have begun to identify the specific genetic markers associated with political conservatism and liberalism (e.g., Hatemi, et al. (2011)). In a recent interview, John Hibbings (Foundation Regents University Professor at the University of Nebraska) estimates that $40-50 \%$ "of our political beliefs seem to have a basis in genetics." 11

If hedge fund managers' underlying psychological characteristics influence their decisions, then this literature suggests that hedge fund managers' political orientation will impact both the securities they select and their portfolio characteristics. Specifically, we hypothesize that more politically conservative hedge fund managers will tend to have less exposure to stocks with greater uncertainty—smaller stocks, younger companies, more volatile stocks, unprofitable companies, and lottery-type securities — than their more politically liberal counterparts. Moreover, we expect that more politically liberal hedge fund managers will exhibit a greater willingness to enter and exit security positions and to adjust their exposure to U.S. equities than their more politically conservative counterparts.

\subsection{Psychological characteristics and financial decisions}

A number of recent studies suggest that individual investors' psychological characteristics impact their investment decisions.12 For instance, individuals who experience low stock returns during their lives are less likely to enter equity markets, expect lower future stock returns, and allocate less to equities (Malmendier and Nagel (2011)). Similarly, investors who grew up during the depression,

11 See http://www.livescience.com/4454-political-preference-genetic.html.

12 Although we focus on the role of psychological characteristics on investors' decisions, a related literature examines whether CEOs' decisions are influenced by their psychological characteristics. For instance, CEOs who enter the job market during a recession or grew up during the depression make more conservative management decisions (e.g., lower leverage and more diversification) and CEOs with prior military experience pursue more aggressive corporate policies (e.g., Schoar and Zuo (2016), Malmendier, Tate, and Yan (2011)). 
entered the job market during poor economic conditions, or grew up in lower socioeconomic status exhibit a preference for value stocks (Cronqvist, Siegel, and Yu (2015)).

Recent research also demonstrates evidence of a strong genetic component to individual investors' financial decision making. For instance, a number of studies that compare decisions of identical versus fraternal twins suggest that 20\%-30\% of variation in financial decision making is determined by genetics (see Cesarini, Dawes, Johnnesson, Lichtenstein, and Wallace (2009), Barnea, Cronqvist, and Siegel, (2010), Cesarini, Johannesson, Lichtenstein, Sandewall, and Wallace (2010), Cronqvist, Seigel, and Yu (2014), Cesarini, Johannesson, Magnusson, and Wallace (2012)). Moreover, recent neurobiological studies have identified specific genetic markers associated with financial risk taking (e.g., Zhong, Isreal, Xue, Sham, Ebstein, and Chew (2009), Dreber et al. (2009), Kuhnen, Samanez-Larkin, and Knutson (2013)). In fact, the same gene (DRD4-7R) has been associated with both increased financial risk taking (Kuhnen and Chiao (2009)) and political liberalism (Settle et al. (2010)).

Although most work relating psychological or cultural characteristics to investment decisions focuses on individual investors, two recent studies examine the relation between institutional investors' decisions and their managers/employees' psychological characteristics. Consistent with evidence (e.g., Halek and Eisenhauer (2001)) that Catholics are more likely to gamble than Protestants, Shu, Sulaeman, and Yeung (2012) report that "Catholic" mutual funds (e.g., those located in primarily Catholic areas) tend to exhibit higher turnover and more aggressive trading than "Protestant" mutual funds. Similarly, Kumar, Page, and Spalt (2011) find that smaller institutional investors located in primarily Catholic areas are more likely to hold lottery-type stocks than institutions located in primarily Protestant areas. 


\subsection{Psychological characteristics and hedge funds' portfolio and security selection decisions}

Although recent work finds evidence of a link between psychological characteristics and the security selection and portfolio decisions of mutual funds or smaller institutional investors, the relation between psychological characteristics and hedge funds' decisions remains largely uninvestigated. As noted in the introduction, however, hedge funds fundamentally differ from other types of institutions. First, hedge funds are at the top of the financial sophistication ladder and a large body of work suggests that the influence of psychological factors declines with investor sophistication (e.g., Grinblatt and Keloharju (2001), Vissing-Jorgensen (2003), Feng and Seasholes (2005), Dhar and Zhu (2006), Kao (2007), Barone and Magilke (2009), Liu, Wang, and Zhao (2010), Seru, Shumway, and Stoffman (2010), Victoravich (2010), List (2011)). Thus, even if psychological characteristics influence the investment decisions of some mutual funds and smaller institutions, it does not imply that psychological characteristics influence the decisions of the most sophisticated investor group-hedge funds. Moreover, the impact of psychological characteristics on some investors' decisions will have negligible asset pricing implications as long as a sufficiently funded group of traders who are immune to these influences exploit the trades of less sophisticated investors (including mutual funds and smaller institutions). Moreover, hedge funds have grown to become a very important market participant accounting for $10 \%$ of the average stock's ownership and one-third of NYSE volume (Cao, Liang, Lo, and Petrasek (2015)). In sum, understanding whether hedge funds' decisions are related to their managers' psychological characteristics is critical to understanding how markets function.13

An additional advantage of focusing on hedge funds is that hedge fund managers have much greater freedom in their security selection and portfolio decisions than other institutional investors.

13 As noted in the introduction, it appears widely accepted (e.g., Brunnermeier and Nagel (2004), Stein (2009)) that hedge funds are viewed as the most sophisticated investor class. Nonetheless, there is anecdotal evidence that some hedge fund managers believe that psychological factors (negatively) influence their decisions. Petersen (2014) reports, for example, that Tudor "...employs clinical and academic psychologist Brett Steenbarger, PhD, who specializes in trader psychology and short-term therapies, to coach Tudor portfolio managers and traders." 
Hedge funds, for instance, are much more willing than other institutions to deviate from benchmarks (e.g., Sias, Turtle, and Zykaj (2016)). Thus, hedge fund portfolios likely reflect their managers' own views more so than other types of institutions. A mutual fund with a small capitalization benchmark, for example, will hold small capitalization stocks regardless of the manager's psychological characteristics.

As far as we are aware, only one previous study has examined the relation between political orientation and institutional investors' investment decisions.14 In an interesting study, Hong and Kostovetsky (2012) find that politically liberal mutual funds are less likely to hold socially irresponsible securities (e.g., stocks with low KLD scores for community activities, diversity, employee relations, and environmental records) and securities from politically sensitive industries (e.g., tobacco) than politically conservative mutual funds. Although their study focuses on mutual funds, they include one table (Table 8) that includes a very brief analysis of hedge fund holdings.

There are several important differences between Hong and Kostovetsky's (2012) work and our study. First, they investigate the relation between institutions' political orientation and a political issue - the social responsibility/irresponsibility of the underlying company. Thus, as the authors point out, the relation between institutional investors' political orientation and social responsibility could result from either political values (e.g., a politically liberal fund manager believes it is inherently wrong to hold a tobacco stock) or because political orientation reflects managers' psychological characteristics and their resulting view of the risk-return characteristics of politically sensitive stocks (e.g., a politically liberal fund is more likely than a politically conservative manager to view a tobacco

\footnotetext{
14 Agarwal, Lu, and Ray (2014) examine hedge fund managers' contributions to non-profit charities (note that political donations are not charitable contributions). Specifically, the authors focus on how hedge fund managers' charitable contributions influence the managers' attention to the fund, the fund flows, and the fund returns. In addition, Lu, Ray, and Teo (2016) examine the relation between hedge fund managers' attention to their funds and marriage and divorce. Although both of these studies provide interesting evidence of hedge fund manager behavior, neither study examines the fundamental economic question evaluated in our study: whether a hedge fund mangers' psychological characteristics influence their security selection and portfolio decisions. Bodnaruk and Simonov (2016) find interesting evidence of crosssectional variation in Swedish mutual fund managers' loss aversion and their behavior.
} 
stock as a poor expected return to risk option). Alternatively, by design, we investigate the relation between hedge funds' political orientations and security and portfolio characteristics that have no direct link to political orientation. For instance, there is no political belief that would cause a politically liberal hedge fund to hold more non-dividend paying stocks or exhibit a greater willingness to enter new securities and exit existing positions relative to a politically conservative hedge fund. In short, because we focus on security selection and portfolio decisions that have no direct link to politics, our results suggest that the relation between political donations and investment decisions reflects underlying differences in psychological characteristics rather than political views.

Second, the authors find little evidence of a meaningful relation between bedge funds' holdings of politically sensitive securities/industries and political donations—of the 20 tests reported in their Table 8, 17 do not differ meaningfully from zero at the 5\% level or better.15 In contrast, we find strong support for the hypothesis that psychological characteristics influence hedge fund managers' decisions. For example, in our strictest tests— controlling for both hedge fund manager characteristics and hedge fund characteristics_-our results are statistically significant at the 5\% level or better in every case.

Third, the relation between institutional investors' (both mutual funds and hedge funds) political donations and the political characteristics of the underlying securities could represent, at least in part, a clientele effect.16 Institutions with a politically liberal investor base may attempt to ingratiate themselves with clients by both giving to Democratic causes (even if they do not inherently support such causes) and investing in socially responsible companies. Consistent with this interpretation of Hong and Kostovetsky's (2012) results, Hong and Kacperczyk (2009) find evidence that some institutional investors avoid "sin" stocks (which have overlap with socially irresponsible stocks) due

15 The studies are not directly comparable because we focus on different variables and differences in samples (e.g., our sample is $162 \%$ larger than their sample).

16 In addition, we believe this is especially unlikely in our case (that focuses on stock characteristics related to speculative nature), however, as evidence (e.g., Credit Suisse (2014)) suggests that more than $85 \%$ of hedge fund clients and assets are institutional. 
to social norms and Agarwal, Lu, and Ray (2014) find that hedge fund managers' donations to nonprofit charities is motivated, in part, as an attempt to attract additional capital and clients.

In contrast, because the characteristics we focus on are non-political metrics of valuation subjectivity identified in the finance literature, our results are unlikely to be driven by hedge funds' attempting to appeal to clients with their security selection decisions. It is possible, of course, that clientele effects arise as a result of the link between political beliefs and psychological characteristics. For instance, it is possible that politically conservative clients are repulsed by hedge funds that hold stocks with highly subjective valuations. Such effects, however, would not change our conclusionour evidence suggests hedge fund managers' decisions are influenced by their psychological characteristics (regardless of whether their clients' decisions are also influenced by the same psychological characteristics).

\section{Data}

Security characteristics are from the Center for Research in Security Prices (CRSP) monthly data files and Compustat quarterly files. Hedge funds' quarterly equity holdings between March 2000 and December 2012 come from Thomson Reuters data derived from hedge funds' 13(f) filings.17 Our sample includes all ordinary shares (CRSP share code 10 or 11) from the New York Stock Exchange (NYSE), American Stock Exchange (Amex), and Nasdaq with adequate CRSP and Compustat data. We require hedge funds to hold at least 25 ordinary securities with adequate data to be included in the sample. Political contributions are from the Federal Election Committee (FEC) website (www.fec.gov) that provides data on all federal political contributions since 1979.

17 All institutions (including hedge funds) with more than $\$ 100$ million in equity ownership must report their equity holdings consisting of either more than 10,000 shares or $\$ 200,000$ in value. 
We use a proprietary list of hedge funds filing 13(f) reports provided by Thomson Reuters.18 Because 13(f) reports are filed at the company level (e.g., long equity holdings of all Tudor hedge funds are reported in the same 13(f) report) and our examination of holdings is based on the 13(f) data, in general, we use the terms "hedge fund" and "hedge fund firm" interchangeably for ease of exposition. (We do not use these terms interchangeably when we examine the relation between portfolio characteristics and fund characteristics, e.g., Section 4.4). The Thomson Reuters 13(f) data only include hedge funds' long equity positions and ignore short positions and derivatives (recent work suggests option positions account for a very small portion of hedge fund portfolio value).19 Although this means we do not examine hedge funds' entire portfolios, it does not bias our tests. That is, we hypothesize that, relative to politically liberal hedge funds, politically conservative hedge funds will exhibit a stronger preference for more conservative securities in their long-equity portfolios.20

In addition, small positions (less than 10,000 shares and $\$ 200,000$ ) are not required to be reported in 13(f) filings and small hedge funds (less than $\$ 100$ million in 13(f) securities) are not required to file 13(f) reports. Moreover, the SEC sometimes allows institutions to file confidentially.21 Nonetheless, the 13(f) data provide distinct snapshots of hedge funds' long equity portfolios and do not suffer from self-selection biases.22

18 See Sias, Turtle, and Zykaj (2016) for additional detail.

19 For example, Aragon and Martin (2012) report (see their Table 2) that the dollar value of securities underlying the options account for less than 5\% of their total equity value of hedge funds filing 13(f) reports.

${ }_{20}$ Unlike long equity holdings, the relation between political orientation and hedge funds' short positions is theoretically ambiguous. More conservative hedge funds, for instance, may take a larger short position on companies with more subjective valuations because they view such firms as a poor risk-reward choice. Alternatively, more conservative hedge funds may take a larger short position in companies with less subjective valuations because the hedge fund managers believe they better understand fundamental value (and deviations from fundamental values) for securities with less subjective valuations.

21 Agarwal, Jiang, Tang, and Yang (2013) report, however, that the vast majority of hedge fund positions (96\%, inferred from their Table I) are not confidential.

22 A number of recent studies use 13(f) data to examine hedge fund long equity holdings, e.g., Brunnermeier and Nagel (2004), Griffin and Xu (2009), Blume and Keim (2016), Boyson, Helwege, and Jindra (2013), Ben-David, Franzoni, and Moussawi (2012), and Agarwal, Jiang, Tang, and Yang (2013). See Agarwal, Fos, and Jiang (2013) for evidence of the selfselection biases inherent in non-13(f) hedge fund databases. 
We construct the hedge fund political contribution dataset from the FEC's detailed files on individual political contributions. The FEC provides information on all individual's federal political contributions from 1979-2012 to both political committees and candidates. Consistent with Cao, Liang, Lo, and Petrasek (2015), the hedge fund sample is relatively small prior to 2000. Specifically, March 2000 is the first quarter where we can identify at least 100 hedge funds that meet our sample criteria. Thus, we limit the contribution data to 1999-2012. Federal law requires that political donation recipients use "best efforts" to collect donor's personal information including name, address, occupation, and employer for any individual that contributes more than $\$ 200$ (cumulatively over a calendar year) to a committee or candidate. As a result, the employer field is non-missing in more than $87 \%$ of observations for the FEC database in our sample period.

We merge hedge fund names in the Thomson Reuters 13(f) filings database with reported employers from the FEC individual contribution database.23 Following Hong and Kostovetsky (2012) we classify hedge funds' political affiliations based on the FEC individual donor donations, i.e., the hedge funds' political orientations can, and often do, represent multiple individuals donating from one hedge fund. We differ from Hong and Kostovetsky, however, in that we remove any donation where the donor-based on the reported occupation-appears unlikely to play a role in influencing the portfolio and security selection decisions at the hedge fund (e.g., office administrator or lawyer).24 Thus, for our initial tests, we classify hedge funds as politically conservative or liberal based on all donations (over the entire 1999-2012 period) associated with any manager or employee (e.g., founder or analyst) who may influence the fund's security selection and portfolio decisions. For readers

23 We use machine matching for initial matches and hand-clean any non-perfectly matched observations to ensure accuracy. 24 The ten most frequently deleted occupations in order from most to least common are: attorney, lawyer, software developer, general counsel, accountant, programmer, human resources, technology consultant, marketing, and graphic designer. Positions such as office administrator, morale manager, etc., are also deleted but are much less common. Nonetheless, our results remain intact when including these observations. 
concerned about pooling donations within each hedge fund company (following Hong and Kostovetsky), in later tests we focus only on donations of hedge fund managers (e.g., founder).25

Our initial tests focus on the broadest sample of hedge funds and the broadest definition of political conservativeness. Specifically, we define hedge fund companies as "Liberal" if more than 50\% of the total dollar value of their donations is to Democrats and "Conservative" if more than $50 \%$ of the total dollar value of their donations is to Republicans. Much of our analysis, however, is based on a stricter definition of political conservatism—we define a hedge fund as "Strong Liberal" if they give at least $70 \%$ of the total dollar value of their donations to Democrats and "Strong Conservative" if they give at least $70 \%$ to Republicans. 26

Our final sample consists of 10,438 hedge-fund quarter observations based on 12,056 total donations from the managers and employees of 494 unique hedge fund companies with contributions totaling $\$ 42,072,503$. (We also gather data on hedge fund characteristics and manager characteristicsthese data are discussed in Sections 4.4 and 4.5, respectively).

The limits associated with the data (e.g., that both 13(f) reports and political donations are at the fund company level rather than the fund level or that 13(f) data excludes small hedge funds) add noise to our tests. This issue is inherent in nearly all studies attempting to link institutional manager characteristics and their security selection and portfolio decisions. Clearly, for example, not all mutual funds (Shu, Sulaeman, and Yeung (2012)) or smaller institutional investors (Kumar, Page, and Spalt

${ }_{25}$ We compute political orientation from hedge fund managers' donations over the entire sample period (following Hong and Kostovetsky (2012)). This is necessary because, as shown below, the typical hedge fund gives relatively few donations over time. Because we use political donations as a proxy for political orientation it makes sense to use the entire sample to minimize measurement error. Implicit in this methodology, however, is the assumption that political orientation does not switch between Strong Liberal and Strong Conservative over the sample period. To the extent that this assumption is violated, it reduces the power of our tests.

${ }_{26}$ We use three criteria to identify the political affiliation of the donations to committees. First, the majority of committees report their political party $(76.7 \%$ of the observations in our sample). If the committee does not list a political party, we define the political party of the donation as the political party of the candidate the committee supports $(9.8 \%$ of the observations in our sample). Finally, if a committee does not list a unique candidate it supports, we define the committee's party affiliation as the party of the candidate to whom the committee made the largest donation (the remaining $13.6 \%$ of observations in our sample). 
2011)) located in Boston have 100\% Catholic employees or investors. In short, the limits associated with the data add noise and reduce the power of our tests. Consistent with this interpretation, our results are generally stronger when we (1) limit the sample to managers' donations and (2) control for manager and fund characteristics.

Panel A in Table 1 reports the time-series descriptive statistics of hedge fund classifications across the 52 quarters in our sample (March 2000-December 2012). On average, we identify portfolio holdings for 201 hedge funds each quarter with approximately $45 \%$ classified as Liberal hedge funds and 55\% classified as Conservative hedge funds. Moreover, on average, nearly four out of five hedge funds are classified as either Strong Liberal or Strong Conservative (third to last row in Panel A). The last two rows in Panel A reports the time-series descriptive statistics for the cross-sectional median number of securities held and long-equity portfolio size across hedge funds. The typical hedge fund in our sample holds 59 stocks worth $\$ 405$ million.

[Insert Table 1 about here]

Panels B and C report descriptive statistics regarding donations across the 246 Liberal hedge funds and the 248 Conservative hedge funds, respectively. Panel B reveals that the average Liberal hedge fund makes 23.7 donations - 18.5 donations to Democrats totaling $\$ 63,439$ and 5.2 donations to Republicans totaling $\$ 12,948$ (over the $1999-2012$ period). These values, however, are skewedthe median fund (second column) makes five Democratic contributions and one Republican contribution over this period totaling $\$ 8,350$ to Democrats and $\$ 1,450$ to Republicans. Similarly, Panel C reveals that the median Conservative hedge fund gives $\$ 7,333$ to Republicans in four donations and $\$ 250$ to Democrats in a single donation.

\section{Empirical results}

The method we employ to examine whether psychological characteristics influence hedge funds' decisions follows several recent studies that use political donations to infer psychological 
characteristics of CEOs and equity analysts.27 Given conservatives' lower tolerance for ambiguity, integrative complexity, new experience, uncertainty, and stronger desire for order and structure, we focus on six security characteristics that previous work identifies as capturing valuation subjectivity. The first five characteristics are those used by Baker and Wurgler (2006) to capture a stock's subjective valuation — market capitalization, age, volatility, profitability, and dividends.28 We recognize that these characteristics are related (e.g., profitable companies are more likely to pay a dividend). Directly analogous to Baker and Wurgler, however, we simply use these characteristics to identify stocks with more speculative valuations. We measure size as the natural logarithm of market capitalization, age as the number of months the stock has been listed on CRSP, and volatility as the standard deviation of monthly returns over the previous year (for stocks with at least nine monthly returns). We define profitable companies as those that exhibit positive net income and dividend paying stocks as those that paid a dividend in the previous year. We use indicator variables to identify profitable and dividend paying companies. Appendix A provides details of the construction of all variables.

The sixth characteristic is lottery-type securities as first identified by Kumar (2009). Specifically, we identify securities with above median residual volatility, below median price, and above median idiosyncratic skewness as lottery-type securities following and Kumar, Page, and Spalt (2011).29 Residual volatility and residual skewness are based on daily returns over the previous six months, price is observed at quarter end, and medians are based on all securities in the CRSP daily files with adequate

\footnotetext{
27 Hutton, Jiang, and Kumar (2014) use political orientation (as identified by their political donations) to measure the fiscal conservatism of CEOs. Consistent with the hypothesis that political ideology reflects psychological characteristics that in turn influence CEOs' financial decisions, the authors find that companies managed by politically conservative CEOs have lower debt, lower capital expenditures, lower R\&D expenditures, and less risky investments. Similarly, Jiang, Kumar, and Law (2016) find that politically conservative equity analysts (as identified by their political donations) make more conservative forecasts and earning revisions.

28 Baker and Wurgler (2006) argue that these five "salient characteristics" are monotonically related to a stock's "subjectivity of their valuation." The authors note that the other measures they consider, such as book to market ratios, have (theoretically and empirically) non-monotonic relations with subjectivity.

${ }_{29}$ We use the lottery-type stock definition from Table 6 of Kumar, Page, and Spalt (2011). In their main results, the authors do not include the Kumar (2009) low price filter to identify lottery-type securities in institutional investors' portfolios because institutions' prudent man constraints may deter institutions from holding low priced securities. Because hedge funds have much greater freedom in their security selection than other institutions, we include the price filter.
} 
data (see Appendix A for additional details). As with profitable and dividend-paying companies, we use an indicator variable for lottery-type securities.

We also investigate hedge funds' turnover, entry trades, exit trades, and change in total equity holdings based on the hypothesis that politically conservative hedge funds' greater aversion to change and need for structure will result in lower turnover, less willingness to enter new positions, less willingness to fully liquidate existing positions, and a more constant allocation to U.S. equity markets than their politically liberal counterparts. We define turnover as the minimum of the dollar value of the hedge fund's total purchases or sales within a quarter scaled by the fund's beginning of quarter portfolio value. We use the product of beginning of quarter prices and changes in shares held to estimate the value of purchases or sales following Ben-David, Franzoni, and Moussawi (2012). We winsorize turnover at the 1 and 99 percent levels each quarter to minimize the impact of outliers.

We define each hedge fund-quarter's enter ratio as the number of securities hedge fund $k$ enters in a quarter (i.e., held at the end of the quarter but not the beginning) scaled by the number of securities hedge fund $k$ holds at the end of the quarter (thus, the enter ratio ranges from 0 to 1 ). Analogously, we define each hedge fund-quarter's exit ratio as the number of securities hedge fund $k$ completely liquidates in a quarter (i.e., held at the beginning of the quarter but not the end) scaled by the number of securities the fund holds at the beginning of the quarter (thus, the exit ratio ranges from 0 to 1$)$.

To examine hedge funds' willingness to adjust their U.S. equity exposure, we follow BenDavid, Franzoni, and Moussawi (2012) and compute the percent change in equity holdings for each fund-quarter as the total dollar value of their trades (beginning of quarter price times the difference between the number of split-adjusted shares held at the end of the quarter and the number of shares held at the beginning of the quarter summed over all securities) scaled by the dollar value of their 
equity portfolio at the beginning of the quarter.30 For example, a fund that has a $\$ 200 \mathrm{M}$ beginning of quarter equity portfolio, purchases $\$ 30 \mathrm{M}$ in equities, and sells $\$ 10 \mathrm{M}$ in equities, has a $10 \%$ change in exposure to U.S. equity markets $((30-10) / 200)$. We winsorize the variable at the $5^{\text {th }}$ and $95^{\text {th }}$ percentiles each quarter following Ben-David, Franzoni, and Moussawi. Because we hypothesize that politically liberal hedge funds are more willing to make adjustments to their equity exposure than politically conservative hedge funds, we focus on the absolute value of the ratio (denoted the absolute percent change in equity holdings).

Each quarter we compute each hedge fund's portfolio characteristics as the fund's weighted average of the underlying security characteristics. For instance, if a hedge fund held only two stocks$\$ 100$ in a non-dividend paying stock that had been listed on CRSP for 12 months, and $\$ 900$ in a dividend paying stock that had been listed on CRSP for 24 months, the fund's portfolio age would be 22.8 months (i.e., $(100 / 1000) * 12+(900 / 1000) * 24)$ and the fund's portfolio dividend "indicator" would be 0.9 (i.e., $(100 / 1000) * 0+(900 / 1000) * 1)$.

For ease of exposition, we use the term "more conservative" to describe portfolios with less exposure to securities with the characteristics previous work identifies as reflecting the subjectivity of valuation, lower turnover, lower propensity to enter and exit securities, and more constant exposure to U.S. equities.31

Panel $\mathrm{A}$ in Table 2 reports the time-series descriptive statistics for the mean hedge fund portfolios' characteristics. Given the characteristics of securities in the market vary over time, it is not surprising that the results reveal substantial variation over time in mean portfolio characteristics, e.g.,

\footnotetext{
30 We use beginning of quarter prices times the number of shares traded over the quarter to ensure that changes in ownership reflect trades rather than returns.

31 The characteristics identified by previous work to capture the subjectivity of valuation do not necessarily correspond directly to risk measures, e.g., a dividend paying stock may have a higher beta than a non-dividend paying stock. We do not claim these measures directly capture risks. Rather, we select these metrics because previous work identifies them as indicators of the degree of subjectivity and political science/psychology literature demonstrates that liberals are more tolerant of ambiguity and uncertainty, more open to new experiences, have lower levels of fear, exhibit higher integrative complexity, and have lower needs for order, structure, and closure.
} 
the volatility of the average security in the market (and the average security in hedge funds' portfolios) was greater in December 2008 than December 2006.

[Insert Table 2 about here]

Because, as shown in Table 2, mean portfolio characteristics change over time, each quarter we standardize (i.e., rescale to zero mean, unit standard deviation) portfolio characteristics across all hedge funds in our sample. This eliminates the time-series variation in mean values and allows for easy interpretation of the coefficients. Specifically, a value of $1(-1)$ indicates the hedge fund's portfolio characteristic is one standard deviation larger (smaller) than that of the average hedge fund that quarter. Because the portfolio characteristics are standardized, we also report (in Panel B), the timeseries descriptive statistics for the cross-sectional standard deviation of the raw portfolio characteristics across hedge funds. For instance, the cross-sectional standard deviation of portfolio "Age" across hedge funds averages 102 months.

Our empirical analysis begins by comparing security characteristics for both the broader (Liberals versus Conservatives) and stricter (Strong Liberals versus Strong Conservatives) definitions of political orientation. We then examine differences when: (1) limiting the sample to hedge funds' entry and exit trades, (2) excluding large donors, (3) controlling for fund characteristics, (4) limiting the sample to funds where the hedge fund manager is the largest donor, (5) limiting the sample to donations by hedge fund managers and controlling for manager characteristics, and (6) limiting the sample to donations by hedge fund managers and controlling for both manager and fund characteristics. We also discuss a number of robustness tests in Section 5.

\subsection{Conservative and liberal hedge funds' portfolio characteristics}

The first three columns of Table 3 report the pooled cross-sectional time-series mean standardized portfolio characteristics for Liberal ( $>50 \%$ donations to Democrats) and Conservative ( $>50 \%$ donations to Republicans) hedge funds, as well as their differences, respectively. Because a 
given hedge fund's holdings are not independent over time (i.e., funds often hold a stock for more than a single quarter) we follow Petersen (2009) and Hong and Kostovetsky (2012) and compute $t$ statistics based on standard errors clustered at the hedge fund level.32

[Insert Table 3 about here]

The results in the third column reveal that Liberal hedge funds exhibit greater exposure to smaller stocks and younger stocks, and are more willing to make adjustments to their U.S. equity exposure (statistically significant at the $5 \%$ level or better) than their Conservative counterparts. For example, companies in Liberal hedge funds' portfolios average 0.118 standard deviations smaller size (first column) than the average hedge fund while companies in Conservative hedge funds' portfolios average 0.098 standard deviation larger size (second column) than the average hedge fund. The difference (0.216 standard deviations, third column) is statistically significant at the $5 \%$ level. We also find evidence (marginally significant at the 10\% level) that Liberal hedge funds have greater exposure to unprofitable companies and lottery-type securities than Conservative hedge funds. Although the coefficients have the predicted sign, differences in return volatility, dividend paying, and turnover are not statistically significant at traditional levels (assuming a two-tail test).33

Using the stricter political orientation classifications, the last three columns in Table 3 report the mean portfolio characteristics for Strong Liberals (>70\% donations to Democrats) versus Strong Conservatives (>70\% donations to Republicans) as well as their differences. In seven of eight cases the differences are larger (relative to the less stringent classifications) ranging from 0.131 standard deviations (for the absolute percent change in equity holdings) to 0.265 standard deviations (for average age of the securities held in the portfolio).34 In addition, seven of the eight characteristic

32 Non-parametric Wilcoxon tests yield similar conclusions.

33 Because we make a specific directional prediction, arguably these should be one tail tests. As one tail tests, the differences in return volatility, dividend paying, and turnover are marginally significant at the $10 \%$ level and differences in profitability and lottery-type securities are statistically significant at the $5 \%$ level.

34 As discussed above we standardize portfolio characteristics to account for time-series variation in the characteristics' distributions and to allow for ease in interpreting the evidence. One can approximate the magnitude (in the original scale) 
differences are at least marginally statistically significant. Specifically, we find Strong Liberal hedge funds tend to hold smaller companies, younger companies, unprofitable companies, and non-dividend paying companies, and are more willing to make adjustments to their U.S. equity market exposure than their Strong Conservative counterparts (statistically significant at the $5 \%$ level or better). We also find evidence that Strong Liberal hedge funds hold more volatile stocks and lottery-type stocks (marginally significant at the 10\% level in all three cases) than their Strong Conservative counterparts. The difference between Strong Liberal and Strong Conservative hedge funds' turnover is not statistically significant at traditional levels.

\subsection{Entry and exit trades}

Unless a hedge fund has $100 \%$ portfolio turnover within a quarter, the fund's portfolio characteristics this quarter are mechanically related to their portfolio characteristics last quarter (and therefore are not independent; hence the clustered standard errors in Table 3 following Hong and Kostovetsky (2012)). As an alternative approach, we compute the value-weighted mean characteristics for stocks that enter each hedge fund's portfolio this quarter (i.e., held at the end of quarter $t$, but not held at the beginning of quarter $t$ ). Because we focus only on stocks new to the portfolio, there is no mechanical time-series overlap in these securities for any fund.

Analogous to the examination of portfolio holdings, we compute the value-weighted characteristics of entry trades where the weight is the dollar value of each entry trade scaled by the dollar value of all entry trades by manager $k$ in quarter $t .35$ In addition, rather than turnover, we examine enter ratios for each manager-quarter (recall the enter ratio is the number of securities hedge

of any of the effects as the difference in Table 3 times the mean cross-sectional standard deviations reported in Panel B of Table 2. For instance, the 0.265 difference for age implies that securities in Strong Conservatives' portfolios average approximately 27 months (i.e., $0.265 * 101.915$ ) older than securities in Strong Liberals' portfolios.

35 For example, if a manager enters two stocks - investing $\$ 1,000$ in a non-dividend paying stock and $\$ 9,000$ in a dividend paying stock - the value-weighted dividend indicator for entry trades is 0.9 (i.e., $0.1 * 0+0.9 * 1$ ). The dollar value of the entry trade is computed as the number of shares held at the end of the quarter times the end of quarter price. The typical hedge fund makes 19 entry trades each quarter (time-series average of cross-sectional median). 
fund $k$ enters in quarter $t$ normalized by the number of securities fund $k$ holds at the end of quarter $t$ and ranges from 0 to 1 ). As before, to easily gauge the economic magnitude of the differences and to control for time-series variation in distributions of stock characteristics (see Table 2), each quarter we standardize the entry portfolio characteristics across all hedge funds in our sample. Because these positions do not overlap over time, we compute differences (between liberals and conservatives) each quarter and generate statistical inferences from the time-series of these quarterly differences.

We also examine the characteristics of exit trades that, analogous to entry trades, have no overlap for a given manager over adjacent quarters. Specifically, we compute the value-weighted exit trade characteristic as the dollar value of the exit trade of security $i$ in quarter $t$ by manager $k$, scaled by the dollar value of all exit trades by manager $k$ in quarter $t .36$ Similarly, we compare exit ratios for politically liberal and conservative hedge funds (recall the exit ratio is the number of securities hedge fund $k$ completely liquidates in quarter $t$ normalized by the number of securities hedge fund $k$ holds at the beginning of quarter $t$ and ranges from 0 to 1). As with entry portfolios, the exit portfolio characteristics are standardized (rescaled each quarter to zero mean, unit variance) across all hedge funds each quarter.

To conserve space, we limit the sample to Strong Liberal and Strong Conservative funds for the balance of the study. The first three columns in Table 4 report the time-series average $(n=52$ quarters) of the cross-sectional mean (across hedge funds) standardized entry portfolio characteristics across Strong Liberal and Strong Conservative hedge funds as well as their differences. The $t$-statistics reported in the third column are based on the time-series of the difference in mean estimates computed with Newey-West (1987) standard errors. The results in the third column reveal that Strong Liberal hedge funds are more likely than their Strong Conservative counterparts to purchase smaller

36 The dollar value of the exit trade is computed as the number of shares held at the beginning of the quarter times beginning of quarter price. The typical hedge fund makes 18 exit trades each quarter (time-series average of cross-sectional median). 
stocks, younger companies, high volatility stocks, companies operating at a loss, non-dividend paying stocks, and lottery-type securities. Strong Liberal funds also exhibit a meaningfully higher enter ratio than their Strong Conservative counterparts. All differences are statistically significant at the 1\% level. The economic magnitudes of the effects indicate that the differences between Strong Liberal and Strong Conservative hedge funds' purchases range from 0.080 standard deviations (return volatility) to 0.165 standard deviations (dividend paying).

[Insert Table 4 about here]

We hypothesize that politically conservative hedge funds tend to sell more conservative securities (relative to politically liberal hedge funds) because politically conservative hedge funds tend to buy, and therefore hold, conservative stocks in their portfolios. For instance, if politically conservative hedge funds tend to hold older stocks in their portfolios (relative to politically liberal hedge funds), they will tend to sell older stocks (relative to politically liberal hedge funds).37 The results in the last three columns of Table 4 are consistent with our hypothesis—Strong Liberal hedge funds are more likely to exit smaller stocks, younger stocks, high volatility stocks, companies operating at a loss, non-dividend paying stocks, and lottery-types securities than their Strong Conservative counterparts (statistically significant at the $5 \%$ level or better in every case). We also find that Strong Liberal hedge funds exhibit a meaningfully (statistically significant at the $1 \%$ level) larger exit ratio than their Strong Conservative counterparts.

\subsection{Are hedge funds attempting to buy performance?}

As pointed out by Hong and Kostovetsky (2012), it is possible that institutional investors make political contributions in an attempt to improve the performance of their holdings through legislation.

37 We hypothesize that politically conservative hedge funds will tend to sell more conservative securities (relative to politically liberal hedge funds) because politically conservative hedge funds tend to buy, and therefore hold, conservative stocks in their portfolio. It is also possible that some security characteristics (e.g., volatility) change over time and that change may influence hedge funds' sell decisions. We focus on characteristic levels, rather than changes, however, because the security characteristics are comparatively stable over hedge funds' holding periods. 
This seems an unlikely scenario in our study for two reasons. First, as discussed above, the characteristics we examine are not related to politics by design. For instance, we do not expect that giving to Republican candidates would benefit older firms more so than younger firms. Second, the typical hedge fund donation is relatively modest and unlikely to "buy" influence. Moreover, previous studies contend that political contributions should be viewed as a consumption good rather than an investment (e.g., Ansolabehere, de Figueiredo, and Snyder (2003)) because there is no evidence that political donations buy influence.

Nonetheless, as a test of this explanation, we repeat the analysis in Table 3, but eliminate all large donors - defined as any hedge fund that contributes more than $\$ 100,000$ to either party. This eliminates 49 of the 405 hedge funds that are identified as Strong Liberal or Strong Conservative. The results, reported in Table 5, are consistent with those reported in Table 3. Strong Liberal hedge funds exhibit a greater willingness to hold smaller stocks, younger companies, more volatile stocks, unprofitable companies, non-dividend paying companies, and lottery-type securities than their Strong Conservative counterparts (all statistically significant at the $5 \%$ level or better). Strong Liberal hedge funds also exhibit a greater willingness to adjust their U.S. equity exposure (marginally significant at the $10 \%$ level).

[Insert Table 5 about here]

\subsection{Controlling for hedge fund characteristics}

It is possible that hedge fund characteristics are associated with their willingness to hold securities with more subjective valuations. For example, funds with greater leverage or no lockups may avoid securities with more subjective valuations. Thus, in this section, we control for hedge fund characteristics to more cleanly identify the relation between hedge funds' political orientations and their portfolio characteristics. To examine this issue, we merge, by hedge fund firm name, the hedge fund firms in the 13(f)/political donation sample with hedge fund firms in two of the major hedge 
fund databases: the Hedge Fund Research database and the Morningstar/CISDM database. Because the 13(f) and donation data are at the hedge fund firm level and the hedge fund databases are at the hedge fund level (but also identify the hedge fund firm), some hedge fund firms have multiple hedge funds identified in the databases.38 As a result, in this section we differentiate hedge funds (i.e., data from Hedge Fund Research and Morningstar/CISDM databases) from hedge fund firms (i.e., 13(f) and political donation data).

For each hedge fund firm we gather six variables from the hedge fund databases — a leverage indicator, a lockup indicator, fund age, fund size, fund flows, and fund style. The leverage and lockup indicators equal one if any of the hedge fund firm's individual funds uses leverage or have a lockup period, respectively. Hedge fund age, computed each quarter, is the number of months (divided by 100) since inception of the hedge fund firm's oldest fund. Hedge fund size, is the natural logarithm of the sum of assets under management for all the hedge fund firm's funds. We compute hedge fund company flow as the aggregate flow across all hedge funds reported by the manager (in the Hedge Fund Research and Morningstar/CISDM databases) scaled by beginning of quarter aggregate assets under management for the hedge fund company. Following the literature (e.g., Ben-David, Franzoni, and Moussawi (2012)), we compute flows as end of quarter assets under management less the sum of beginning of quarter assets under management and dollar return.

Hedge fund style identifies one of five primary strategies (the four used by Hedge Fund Research plus Multi-Strategy firms) for each hedge fund firm—Event-Driven, Equity-Hedge, Macro, Relative-Value, and Multi-Strategy.39 If all of the funds associated with a hedge fund firm follow the same primary strategy (as identified in the hedge fund databases), the hedge fund firm is identified as following that strategy (e.g., a firm has three Equity-Hedge funds). If a hedge fund firm has funds that

38 If a hedge fund firm appears in both databases, we use the Hedge Fund Research data.

39 We map CISDM/Morningstar categories to Hedge Fund Research main strategies. See Appendix A for additional detail. 
follow different main strategies (e.g., a Macro fund and an Event-Driven fund), we designate the firm as Multi-Strategy (22\% of our hedge fund firms are classified as Multi-Strategy). We also compute, for each hedge fund firm, an indicator variable for funds located in the Northeast (following Kostovetsky (2009)) based on the mode zip code from donations. (Appendix A provides additional details of our hedge fund firm variables.) Our final sample for this analysis consists of 182 hedge fund firms (87 Strong Liberal and 95 Strong Conservative) for a total of 3,461 hedge fund firm-quarter observations.

To examine differences in portfolio characteristics while controlling for hedge fund firms' characteristics, we estimate a panel regression of hedge fund firms' portfolio characteristics (standardized across all hedge funds each quarter) on hedge fund firm age, hedge fund firm size, hedge fund firm absolute flows, and indicator variables for hedge fund firm styles, hedge fund firms using leverage, hedge fund firms with lockups, and hedge fund firms located in the Northeast. We also include quarterly fixed effects.40 Last, to capture differences between Strong Conservative and Strong Liberal hedge fund firms, we include an indicator variable for Strong Liberal hedge fund firms:

$$
\begin{aligned}
& \text { Standardized Characteri stic }_{k, t}=\sum_{t=1}^{52} \alpha_{t}+\sum_{t=1}^{4} \text { Style }_{k}+\beta_{1} \text { Strong Liberal }_{k}+\beta_{2} \text { Leverage }_{k}+\beta_{3} \text { Lockup }_{k}+
\end{aligned}
$$

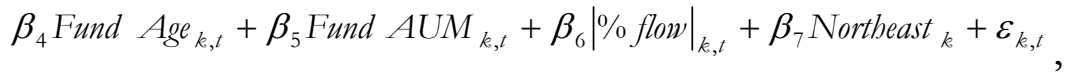

where Standardized Characteristick,t is the standardized value-weighted portfolio characteristic for hedge fund $k$ at the end of quarter $t .41$ Standard errors are clustered at the hedge fund firm level.

Table 6 reports the regression results for each of the standardized characteristics. Most of the coefficients associated with hedge fund firm characteristics are not meaningfully different from zero.

\footnotetext{
40 Because the portfolio characteristics are standardized across all hedge funds in our data (rather than just the hedge funds we match with Hedge Fund Research and Morningstar/CISDM data), the mean portfolio characteristic differs from zero and, as a result, we include quarterly fixed effects to control for any time-series variation in mean values. Nonetheless, we find nearly identical results when estimating without fixed effects.

41 Because we have both fixed time effects and indicator variables for the hedge fund firm style, we only include fund style controls for four fund styles to avoid a dummy variable trap (thus, the fixed time effects reflect the effect for the omitted style category).
} 
We do find, however, that older hedge fund firms are more willing to hold smaller stocks, younger companies, and unprofitable companies and less willing to make adjustments to their U.S. equity exposure. Larger hedge fund firms favor larger stocks, older companies, dividend paying companies, and avoid lottery-type securities.42 Hedge funds located in the northeast also appear to avoid lotterytype securities. We also find the intuitive result that hedge funds with greater absolute flows average greater turnover and greater absolute changes in their U.S. equity exposures.

[Insert Table 6 about here]

The coefficients associated with the Strong Liberal indicator variable reveal that when controlling for hedge fund firm characteristics, Strong Liberal hedge fund firms are more willing to hold smaller stocks, younger companies, high volatility stocks, non-dividend paying companies, and lottery-type securities (statistically significant at the 5\% level or better). We also find evidence that Strong Liberal hedge fund firms have greater exposure to unprofitable companies and are more willing to make adjustments to their U.S. equity exposure (marginally significant at the $10 \%$ level). Although the point estimate is in the expected direction, we cannot reject the hypothesis that Strong Liberal hedge fund firms and Strong Conservative hedge fund firms exhibit similar turnover.

Because the dependent variable is standardized across all hedge fund firms each quarter, the coefficient associated with the Strong Liberal indicator has a straightforward interpretation-it represents the standard deviation change in the portfolio characteristic when moving from a Strong Conservative hedge fund firm to a Strong Liberal hedge fund firm when holding hedge fund firm characteristics (i.e., the other independent variables) constant. The magnitude of the effect ranges

42 We do not have specific hypotheses regarding how hedge fund characteristics (other than political orientation) may be related to the conservatism of the hedge funds' security selection and portfolio characteristics. Rather, our focus is on testing whether the relation between hedge funds' political orientations and security selection and portfolio decisions remains intact after accounting for variation in fund characteristics. 
from 0.119 standard deviations (absolute percent change in equity holdings) to 0.393 standard deviations (exposure to dividend paying securities).

\subsection{Hedge fund managers' donations}

Although we exclude donations for those individuals unlikely to have a role in security selection and portfolio decisions (e.g., "human resources") it is possible that employees at some hedge funds play a larger role in political contributions than in security selection or portfolio decisions. For instance, an "analyst" at a large fund may have little influence on individual security decisions, but account for a relatively large percentage of the total donations from the fund's employees. The noise caused by these observations, however, would reduce the power of our tests yielding a lower likelihood of rejecting the null hypothesis that hedge funds' political orientations are independent of their security selection and portfolio characteristics.

Nonetheless, to provide a potentially cleaner link between hedge fund managers' psychological characteristics and their security selection and portfolio characteristics, we identify the largest donor for each hedge fund and classify that person as a hedge fund manager or non-manager employee. Our classifications are based on the reported occupation in the political donation data (248 the 494 hedge funds) or, when ambiguous (e.g., occupation reported as "Finance"), we search for additional information on the Internet (246 of the 494 hedge funds). We classify the top donor for each hedge fund as a hedge fund manager (e.g., CEO, President, founder, owner, principal, etc.) or hedge fund non-manager (e.g., trader, analyst, etc.).43

Of the 494 hedge funds in our sample, hedge fund managers are the largest donor in 426 cases ( $86 \%$ of the hedge fund sample). Based only on donations from hedge fund managers (and members

43 We classify the following as hedge fund managers: CEO (and co-CEO), Chairman, Chief Investment Officer, Director of Investments, Founder (or Co-Founder), Founding Partner, Fund Manager, General Partner, Hedge Fund Manager, Investment Manager, Lead Portfolio Manager, Co-Manager, Managing Director, Managing General Partner, Managing Member, Managing Partner (or co-Managing Partner), Owner (or co-Owner), Partner, Portfolio Manager, President, Principal, and Senior Managing Director. We also include two hedge fund managers where the press identifies the fund as either "controlled by" or "run by" the manager. 
of their family who report working for the fund), we reclassify these 426 hedge funds as Strong Liberal if the hedge fund manager gives at least $70 \%$ of their total donations to Democrats and Strong Conservative if they give at least $70 \%$ of their total donations to Republicans. This results in a sample of 373 Strong Conservative ( $n=197$ managers) or Strong Liberal ( $n=176$ managers) hedge fund managers. Not surprisingly, given we focus on the largest donor for each fund, the fund political orientation classifications based on hedge fund manager's donations is the same as the fund's political orientation classification based on all employees' donations for 368 of the 373 hedge funds (99\%).

We then repeat the examination of security characteristics when limiting the sample to funds where a manager is the largest donor and use the political orientation classifications based on the hedge fund manager's donations only. Table 7 reports the mean portfolio characteristics (standardized across all hedge fund firms each quarter) for Strong Liberal hedge funds, Strong Conservative hedge funds, and their differences. Analogous to Table 3, standard errors are clustered by hedge fund.

[Insert Table 7 about here]

Our results remain robust with the revised classification method-Strong Liberal managers have greater exposure to smaller stocks, younger stocks, high volatility stocks, and non-dividend paying companies and exhibit a greater willingness to make adjustments to the U.S. equity market exposure than their Strong Conservative counterparts (statistically significant at the $5 \%$ level or better in all cases). We also find evidence that Strong Liberal managers are more willing to hold unprofitable companies and lottery-type securities, and exhibit greater turnover (all marginally statistically significant at the $10 \%$ level). The economic magnitude of the mean differences ranges from 0.157 standard deviations to 0.275 standard deviations.

\subsection{Controlling for manager characteristics}

Another possibility is that the managers' personal characteristics (beyond their political orientation) are associated with their willingness to hold securities with more subjective valuations. 
For instance, older managers may be more politically conservative and invest more conservatively. These personal characteristics may help explain variation in hedge funds' portfolio conservatism if they are systematically related to psychological characteristics associated with conservatism above and beyond that captured by the manager's political conservatism. Nonetheless, analogous to the hedge fund characteristics controls above, controlling for manager characteristics should allow us to more cleanly identify the relation between hedge funds' political orientations and portfolio characteristics. Specifically, we gather the biographical data used in Kostovetsky's (2009) and Hong and Kostovetsky's (2012) mutual fund analysis: manager age, median SAT of the manager's undergraduate institution in 2005, gender, and an indicator variable for graduate education. 44 We successfully collect the biographical data for 295 of the $373(79 \%)$ largest donors who are managers and either Strong Liberal managers ( $n=143$ managers) or Strong Conservative managers ( $n=152$ managers).

We then estimate a panel regression for each standardized characteristic on an indicator variable for Strong Liberal, manager characteristics, and quarterly fixed effects (analogous to Equation (1)) with standard errors clustered at the hedge fund firm level. Table 8 reports the estimated coefficients based on our sample of 295 managers and 5,959 hedge fund manager firm-quarters. The analysis reveals that the relations between managers' political orientation and security characteristics remain fully intact when accounting for other manager characteristics. Specifically, even when controlling for manager age, gender, graduate education, and median undergraduate SAT, Strong Liberal managers have greater exposure to small stocks, younger companies, high volatility stocks, unprofitable companies, non-dividend paying stocks, and lottery-type securities. We also find evidence that Strong Liberal managers are more willing to adjust their exposure to U.S. equity markets (marginally statistically significant at the 10\% level) than Strong Conservative managers. In general,

44 Note that although we include an indicator variable for gender, males comprise $96 \%$ of the hedge fund managers in our sample. 
we find little evidence that manager characteristics other than political conservatism are systematically related to hedge funds' portfolio conservatism with the exceptions that younger managers exhibit higher turnover and appear more willing to adjust their U.S. equity market exposure.

[Insert Table 8 about here]

\subsection{Controlling for manager characteristics and hedge fund characteristics}

As a final test we control for both manager characteristics and hedge fund firm characteristics. Because we require both manager characteristic data and hedge fund firm characteristic data, the sample size is 131 hedge fund managers (61 Strong Liberal and 70 Strong Conservative) accounting for 2,574 hedge fund firm-quarter observations. Specifically, we control for manager age, gender, graduate degree, median undergraduate SAT, hedge fund firm leverage (indicator variable), hedge fund firm lockup (indicator variable), hedge fund firm age, hedge fund firm size, hedge fund firm absolute flows, indicator variable for northeast location, indicator variables for hedge fund firm styles, and quarterly fixed effects. Standard errors are clustered at the hedge fund firm level.

Table 9 reveals that we find the strongest results in the model controlling for both fund and manager characteristics. Specifically, the evidence continues to demonstrate that Strong Liberal managers tend to exhibit greater exposure to smaller stocks, younger companies, higher volatility stocks, unprofitable companies, non-dividend paying companies, lottery-type securities and exhibit higher portfolio turnover and a greater willingness to adjust their exposure to U.S. equity markets (all coefficients are statistically significant at the 5\% level or better). The economic magnitude of the effects of moving from a Strong Liberal hedge fund to a Strong Conservative hedge fund ranges from 0.180 standard deviations (absolute percent change in equity holdings) to 0.539 standard deviations (natural log of capitalization).

[Insert Table 9 about here]

\section{Discussion}


Although political contributions are the observable metric we use to proxy for a hedge fund's political orientation (which reflects its managers' psychological characteristics), a number of unobservable characteristics (e.g., religiosity) may also serve as an indication of a hedge fund's attitude toward investment conservativeness. Our inability to observe these variables, however, does not change the interpretation of our results. Specifically, our results are consistent with the hypothesis that the psychological characteristics of the most sophisticated investor group impact their security selection decisions, their willingness to exit and enter security positions, and their willingness to adjust equity market exposures.

Following previous work (e.g., Hong and Kostovetsky (2012), Hutton, Jiang, and Kumar (2014)), we use political contributions to infer political orientation. It is likely, of course, that some political contributions are not motivated by political orientation (e.g., a manager giving as a result of peer effects). Once again, the noise caused by the lack of perfect correspondence between political donations and political orientation only reduces the power of our tests. Nonetheless, extant evidence suggests that political contributions do, in general, reflect, political orientation (see, for example, the discussion in Hutton, Jiang, and Kumar). To further examine this issue, we were able to identify 39 hedge fund managers (from Section 4.5) registered as a Republican or Democrat in Connecticut that were: (1) the largest donor for the hedge fund, and (2) identified as a Strong Democrat or Strong Republican. 45 Of those 39 managers, 33 (85\%) matched on their political contribution and party registration. Although political orientation is unobservable, these results support the hypothesis that political contributions reflect political party membership, another indicator of political orientation.

45 Connecticut party registration is gathered from the website connvoters.com. The 2002 Help America Vote Act required each state to collect official state voter rolls. The public availability of these rolls vary from state to state. In Connecticut, the data are publically available. Most states, however, have very restricted access to these data. In New York, for example, it is a crime to use these data for any "non-election purposes." 
Another potential concern is that some types of hedge funds' security selection decisions are likely immune from psychological factors. For example, if some managers take a pure quantitative approach, one may expect that their security selection decisions are unrelated to their political orientation. 46 It is important to recognize, however, that we do not claim our evidence suggests psychological characteristics impact the decisions of all hedge funds. Rather, our evidence suggests that, on average, there is a relation between psychological characteristics and hedge funds' security selection and portfolio decisions. Moreover, most hedge funds do not appear to select broad portfolios of securities as expected if using a quantitative model (e.g., Table I shows that the typical hedge fund holds less than 60 long-equity positions even though their portfolio exceeds $\$ 400 \mathrm{M}$ ).

We also consider the possibility that funds with non-equity-hedge focus (e.g., Macro or MultiStrategy funds) may influence our results. Once again, the additional noise caused by non-equityfocused funds only weakens our tests. Regardless, to examine this possibility we repeat the tests in Table 6 limiting the sample to equity-oriented (as identified by HFR or CISDM) hedge funds only. Consistent with our hypothesis, the results are generally stronger with limiting the sample to equityoriented funds only (untabulated).

Last, our results do not require that hedge funds directly consider the characteristics the literature uses to estimate the degree of subjectivity (e.g., whether a company pays a divided). Rather, as Baker and Wurgler (2006) point out, these characteristics help quantify the degree of subjectivity in valuation. If stocks with highly subjective valuations are less likely to pay a dividend and politically liberal hedge funds are more willing to hold stocks with more subjective valuations, then politically

${ }_{46}$ Of course, it is possible that psychological factors influence the decision to take a quantitative approach. Moreover, the functional form of the model may be related to psychological characteristics. Given the evidence that hedge fund long equity portfolios have very little overlap (Sias, Turtle, and Zykaj (2016)), there must be meaningful cross-sectional variation in the models used by quantitative funds. 
liberal hedge funds will have higher exposure to non-dividend paying stocks (even if they do not directly consider whether a stock pays a dividend in their decision making process).

\section{Conclusions}

Based on well-established psychology and political science research, we use hedge funds' political donations to examine if hedge fund managers' psychological characteristics influence their security selection and portfolio decisions. We find that politically liberal hedge funds tend to hold less conservative portfolios. Specifically, politically liberal hedge funds exhibit greater exposure to smaller stocks, less mature companies, more volatile stocks, unprofitable companies, non-dividend paying stocks, and lottery-type stocks relative to their politically conservative counterparts. Further consistent with the hypothesis that psychological characteristics influence their portfolio decisions, politically liberal hedge funds exhibit, on average, a greater willingness to completely exit a security, enter a new equity position, and to make larger adjustments to their U.S. equity market exposure than their politically conservative counterparts. We find no evidence that hedge fund or manager characteristics subsume the relations between hedge funds' political orientations and portfolio characteristics. In short, regardless of how we frame the tests, we find evidence that hedge funds' political conservatism is related to the conservativeness of their security selection and portfolio decisions. Our results provide the first evidence that psychological characteristics influence the decisions of those investors at the very top of the financial sophistication ladder who are assumed to correct any mispricing induced by other, less sophisticated, investors. 


\section{Acknowledgments}

We thank Danling Jiang, Eric Kelley, Leonard Kostovetsky, Kelvin Law, and seminar participants at the 2013 Southern Finance Association Meetings, the 2013 Financial Management Association Meetings, the 2015 European Finance Association Meetings, and the University of Arizona. 


\section{References}

Abramowitz, A.I., Saunders, K.L., 2006. Exploring the bases of partisanship in the American electorate: Social identity vs. ideology, Political Research Quarterly 59, 175-187.

Abramowitz, A.I., Saunders, K.L., 2008. Is polarization a myth?, Journal of Politics 70, 542-555.

Adorno, T.W., Frenkel-Brunswik, E., Levinson, D., Sanford, N., 1950. The Authoritarian Personality. New York, NY: Harper and Row.

Agarwal, V., Fos, V., Jiang, W., 2013. Inferring reporting-related biases in hedge fund databases from hedge fund equity holdings, Management Science 59, 1271-1289.

Agarwal, V., Jiang, W., Tang, Y., Yang, B., 2013. Uncovering hedge fund skill from the portfolio holdings they hide, Journal of Finance 68, 739-783.

Agarwal, V., Lu, Y., Ray, S., 2014. What happens when your money manager gives money away? An analysis of hedge fund managers' charitable donations, Working paper, Georgia State University.

Ahn, W., Kishida, K.T., Gu, X., Lohrenz, T., Harvey, A., Alford, J.R., Smith, K.B., Yaffe, G., Hibbing, J.R., Dayan, P., Montague, P.R., 2014. Nonpolitical images evoke neural predictors of political ideology, Current Biology 24, 1-7.

Akbas, F., Armstrong, W.J., Sorescu, S.M., Subrahmanyam, A., 2015. Smart money, dumb money, and capital market anomalies, Journal of Financial Economics 118, 355-382.

Alford, J.R., Funk, C.L., Hibbing, J.R., 2005. Are political orientations genetically transmitted? American Political Science Review 99, 153-167.

Amodio, D.M., Jost, J.T., Master, S.L., Yee, C.M., 2007. Neurocognitive correlates of liberalism and conservatism, Nature Neuroscience. 10, 1246-1247.

Ansolabehere, S., de Figueiredo, J.M., Snyder Jr., J.M., 2003. Why is there so little money in U.S. politics?, Journal of Economic Perspectives 17, 105-130.

Aragon G., Martin, S. 2012. A unique view of hedge fund derivatives usage: Safeguard or speculation, Journal of Financial Economics 105, 436-456.

Baker, M. and Wurgler, J., 2006. Investor sentiment and the cross-section of stock returns, Journal of Finance 61, 1645-1680.

Barnea, A., Cronqvist, H., Siegel, S. 2010. Nature or nurture: What determines investor behavior?, Journal of Financial Economics 98, 583-604.

Barone, G.J., Magilke, M.J., 2009. An examination of the effects of investor sophistication on the pricing of accruals and cash flows, Journal of Accounting, Auditing \& Finance 24, 385-414.

Baquero, G., ter Horst, J., Verbeek, M., 2005. Survival, look-ahead bias, and persistence in hedge fund performance, Journal of Finance and Quantitive Analysis 40, 493-517.

Ben-David, I., Franzoni, F., Moussawi, R., 2012. Hedge fund stock trading during the financial crisis of 20072009, Review of Financial Studies 25, 1-54. 
Blume, M.E., Keim, D.B., 2016. The changing nature of institutional stock investing, Critical Finance Review, forthcoming

Bodnaruk, A., Simonov, A., 2016. Loss averse preferences, performance, and career success of institutional investors, Review of Financial Studies, forthcoming.

Boyson, N., Helwege, J., and Jindra, J., 2013. Crises, liquidity shocks, and fire sales at hedge funds, Working paper, Northeastern University.

Brav, A., Jiang, W., Partnoy, F., Thomas, R., 2008. Hedge fund activism, corporate governance, and firm performance, Journal of Finance 63, 1729-1775.

Brunnermeier, M.K.. Nagel, S., 2004. Hedge funds and the technology bubble, Journal of Finance 59, $2013-$ 2040.

Campbell, J.Y., 2006. Household finance, Journal of Finance 61, 1553-1604.

Campbell, A., Converse, P., Miller, W., and Stokes, D., 1960. The American Voter, Chicago, IL: University of Chicago Press.

Cao, C., Chen, Y., Goetzmann, W.N., Liang, B., 2015. The role of hedge funds in the security price formation process, Working paper, Pennsylvania State University.

Cao, C., Liang, B., Lo, A.W., Petrasek, L., 2015. Hedge fund holdings and stock market efficiency, Working paper, University of Massachusetts Amherst.

Cesarini, D., Dawes, C.T., Johannesson, M., Lichtenstein, P., and Wallace, B., 2009. Genetic variation in preferences for giving and risk taking, Quarterly Journal of Ecnonomics 124, 809-841.

Cesarini, D., Johannesson, M., Lichtenstein, P., Sandewall, O., Wallace, B., 2010. Genetic variation in financial decision-making, Journal of Finance 65, 1725-1753.

Cesarini, D., Johannesson, M., Patrik, Magnusson, K.E., Wallace, B., 2012. The behavioral genetics of behavioral anomalies, Management Science 58, 21-34.

Credit Suisse., 2014. Onwards and upwards the 2014 Credit Suisse global survey of hedge fund investor appetite and activity, Credit Suisse Group.

Cronqvist, H., Siegel, S., Yu, F., 2015. Value versus growth investing: Why do different investors have different styles?, Journal of Financial Economics 117, 333-349.

Curcuru, S.E., Heaton, J., Lucas, D., Moore, D., 2009. Heterogeneity and portfolio choice: Theory and evidence. in Ait-Sahalia and Lars Peter Hansen, ed. Handbook of Financial Econometrics, Amsterdam, NL: Elsevier, 337-381.

Dhar, R., Zhu, N., 2006. Up close and personal: Investor sophistication and the disposition effect, Management Science 52, 726-740.

Dreber, A., Coren, A.L., Eisenberg, D.T.A., Garcia, J.R., Samore, R.S., Lum, J.K., Campbell, B., 2009. The 7R polymorphism in the dopamine $\mathrm{D}_{4}$ receptor gene (DRD4) is associated with financial risk-taking in men, Evolution and Human Behavior 30, 85-92. 
Fama, E.F., 1965. The behavior of stock-market prices, Journal of Business 38, 34-105.

Feng, L., Seasholes, M.S., 2005. Do investor sophistication and trading experience eliminate behavioral biases in financial markets?, Review of Finance 9, 305-351.

Friedman, M., 1953. Essays in positive economics, Chicago, IL: University of Chicago Press.

Getmansky, M., Lo, A.W., Makarov, I., 2004. An econometric model of serial correlation and illiquidity in hedge fund returns, Journal of Financial Economics 74, 529-609.

Griffin, J.M., Xu, J., 2009. How smart are the smart guys? A unique view from hedge fund stock holdings, Review of Financial Studies 22, 2531-2570.

Grinblatt, M., Keloharju, M., 2001. How distance, language, and culture influence stockholdings and trades, Journal of Finance 56, 1053-1073.

Halek, M., Eisenhauer, J.G., 2001, Demography and risk aversion, Journal of Risk and Insurance 68, 1-24.

Hatemi, P.K., Gillespie, N.S., Eaves, L.J., Maher, B.S., Webb, B.T., Heath, A.C., Medland, S.E., Smyth, D.C., Beeby, H.N., Gordon, S.D., Montgomery, G.W., Zhu, G., Byrne, E.M., Martin, N.G., 2011. A genome-wide analysis of liberal and conservative political attitudes, Journal of Politics 73, 271-285.

Hong, H., Kacperczyk, M., 2009. The price of sin: The effects of social norms on markets, Journal of Financial Economics 93, 15-36.

Hong, H., Kostovetsky, L., 2012. Red and blue investing: Values and finance, Journal of Financial Economics 103, 1-19.

Hutton, I., Jiang, D., Kumar, A., 2014. Corporate policies of Republican managers, Journal of Financial and Quantitative Analysis 49, 1279-1310.

Jiang, D., Kumar, A., Law, K., 2016. Political contributions and analyst behavior, Review of Accounting Studies 21, 37-88.

Jost, J.T., 2006. The end of the end of ideology, American Psychology 61, 651-670.

Jost, J.T., Glaser, J., Kruglanski, A.W., and Sulloway, F.J., 2003. Political conservatism as motivated social cognition, Psychological Bulletin 129, 339-375.

Kam, C.D., Simas E.N., 2010. Risk orientations and policy frames, Journal of Politics 72, 381-396.

Kao, L., 2007. Does investors' sophistication affect persistence and pricing of discretionary accruals?, Review of Pacific Basin Financial Markets \& Policies 10, 33-50.

Kanai, R., Feilden, T., Firth, C., Rees, G., 2011. Political orientations are correlated with brain structure in young adults, Current Biology 21, 677-680.

Kostovetsky, L., 2009. Brain drain: Are mutual funds losing their best minds?, Working paper, Boston College.

Kuhnen, C.M., Chiao, J.Y., 2009. Genetic determinants of financial risk taking, PLoS ONE 4, 1-4. 
Kuhnen, C.M., Samanez-Larkin, G.R., Knutson, B., 2013. Serotonergic genotypes, neuroticism, and financial choices, PLoS ONE 8, 1-9.

Kumar, A., 2009. Who gambles in the stock market?, Journal of Finance 64, 1889-1933.

Kumar, A., Page, J.K., Spalt, O.G., 2011. Religious beliefs, gambling attitudes, and financial market outcomes, Journal of Financial Economics 102, 671-708.

List, J.A., 2011. Does market experience eliminate market anomalies? The case of exogenous market experience, American Economic Review 101, 313-317.

Liu, Y., Wang, M., Zhao, L., 2010. Narrow framing: Professions, sophistication, and experience, Journal of Futures Markets 30, 203-229.

Lu, Y., Ray, S., Teo, M., 2016. Limited attention, marital events, and hedge funds, Journal of Financial Economics, forthcoming.

Malmendier, U., Nagel, S., 2011. Depression babies: Do macroeconomic experiences affect risk taking?, Quarterly Journal of Ecnonomics 126, 373-416.

Malmendier, U., Tate, G., Yan, J., 2011. Overconfidence and early-life experiences: The effect of managerial traits on corporate financial policies, Journal of Finance 66, 1687-1733.

Newey, W., West, K.D., 1987. A simple, positive semi-definite, heteroskedasticity and autocorrelation consistent covariance matrix, Econometrica 55, 703-708.

Petersen, M.A., 2009. Estimating standard errors in financial panel data sets: Comparing approaches, Review of Financial Studies 22, 435-480.

Petersen, R., 2014. Neurofinance. In: Baker, K., Ricciardi, V. (Eds), Investor Behavior: The Psychology of Financial Planning and Investing, Hoboken, NJ: John Wiley and Sons, 381-401.

Schoar, A., Zuo, L. 2016. Shaped by booms and busts: How the economy impacts CEO careers and management styles, Working paper, Massachusetts Institute of Technology.

Schreiber, D., Fonzo, G., Simmons, A.N., Dawes, C.T., Flagan, T., Fowler, J.H., Paulus, M.P., 2013. Red brain, blue brain: Evaluative processes differ in Democrats and Republicans, PLoS ONE 8, 1-6.

Seru, A., Shumway, T., Stoffman N., 2010. Learning by trading, Review of Financial Studies 23, 705-739.

Settle, J.E., Bond, R.M., Levitt, J., 2011. The social origins of adult political behavior, American Politics Research 39, 239-263.

Settle, J.E., Dawes, C.T., Fowler, J.H., 2009. The heritability of partisan attachment, Political Research Quarterly 62, 601-613.

Settle, J.E., Dawes, C.T., Christakis, N.A., Fowler, J.H., 2010. Friendships moderate an association between a dopamine gene variant and political ideology, Journal of Politics 72, 1189-1198.

Shu, T., Sulaeman, J., Yeung, P.E., 2012. Local religious beliefs and mutual fund risk-taking behaviors, Management Science 58, 1779-1796. 
Sias, R.W., Turtle, H.J., Zikaj, B., 2016. Hedge fund crowds and mispricing, Management Science 62, 764-784.

Stein, J.C., 2009. Sophisticated investors and market efficiency, Journal of Finance 64, 1517-1548.

Victoravich, L.M., 2010. Overly optimistic? Investor sophistication and the role of affective reactions to financial information in investors' stock price judgments, Journal of Behavioral Finance 11, 1-10.

Vissing-Jorgensen, A., 2003. Perspectives on behavioral finance: Does "irrationality" disappear with wealth? Evidence from expectations and actions, NBER Macroeconomics Ann. 18, 139-208.

Zhong, S., Israel, S., Xue, H., Sham, P.C., Ebstein, R.P., Chew, S.H., 2009. A neurochemical approach to valuation sensitivity over gains and losses, Proceedings of the Royal Society B: Biological Sciences 276, 4181-4188. 


\section{Appendix A}

Definitions

\begin{tabular}{|c|c|c|}
\hline Item & Source & Description \\
\hline \multirow[t]{2}{*}{$\begin{array}{l}\text { Strategy } \\
\text { indicators }\end{array}$} & $\begin{array}{l}\text { Hedge Fund Research database \& } \\
\text { CISDM database }\end{array}$ & $\begin{array}{l}\text { For the Hedge Fund Research database, we use } \\
\text { five strategy indicator variables-the four } \\
\text { "main strategy" categories (Event-Driven, } \\
\text { Equity Hedge, Macro, and Relative-Value) and } \\
\text { a multi-strategy indicator. If all funds managed } \\
\text { by a hedge fund firm operate in the same main } \\
\text { strategy (e.g., three different Equity Hedge } \\
\text { funds), the hedge fund firm is given that } \\
\text { classification. If a hedge fund firm has funds } \\
\text { in different strategies (e.g., a Relative-Value } \\
\text { fund and a Macro fund), the firm is classified } \\
\text { as multi-strategy. }\end{array}$ \\
\hline & & $\begin{array}{l}\text { For the CISDM database, we map the } 32 \\
\text { Morningstar fund categories to the five Hedge } \\
\text { Fund Research categories. In most cases, the } \\
\text { mapping is based on the analogous Hedge } \\
\text { Fund Research sub-strategy. For instance, the } \\
\text { Morningstar "HF Volatility" strategy is } \\
\text { classified as a Relative-Value strategy because } \\
\text { "Volatility" is a substrategy of the Relative- } \\
\text { Value strategy in Hedge Fund Research. }\end{array}$ \\
\hline Fund assets & $\begin{array}{l}\text { Hedge Fund Research database } \& \\
\text { CISDM database }\end{array}$ & $\begin{array}{l}\text { We compute total assets under management for } \\
\text { each hedge fund firm as the sum of the assets } \\
\text { under management for the funds controlled } \\
\text { by the hedge fund firm. Our analysis uses the } \\
\text { natural logarithm of total AUM. The value is } \\
\text { updated every quarter. }\end{array}$ \\
\hline $\begin{array}{l}\text { Leverage } \\
\text { indicator }\end{array}$ & $\begin{array}{l}\text { Hedge Fund Research database } \& \\
\text { CISDM database }\end{array}$ & $\begin{array}{l}\text { The leverage indicator variable equals one if any } \\
\text { fund associated with a hedge fund firm } \\
\text { reports using leverage. For Hedge Fund } \\
\text { Research, we use the variable "leverage" to } \\
\text { identify funds using leverage. For CISDM we } \\
\text { use the variables "use_leverage", "leverage } \\
\text { ratio", and "avg leverage" to identify funds } \\
\text { using leverage. }\end{array}$ \\
\hline
\end{tabular}




\section{Appendix A.}

Definitions (continued)

\begin{tabular}{|c|c|c|}
\hline Item & Source & Definition \\
\hline $\begin{array}{l}\text { Lockup } \\
\text { indicator }\end{array}$ & $\begin{array}{l}\text { Hedge Fund Research database } \& \\
\text { CISDM database }\end{array}$ & $\begin{array}{l}\text { The lockup indicator variable equals one if any } \\
\text { fund associated with a hedge fund firm } \\
\text { reports a lockup period. For Hedge Fund } \\
\text { Research, we use the variable "lockup" to } \\
\text { identify funds using lockups. For CISDM we } \\
\text { use the variable "lockup months" to identify } \\
\text { funds using lockups. }\end{array}$ \\
\hline Fund age & $\begin{array}{l}\text { Hedge Fund Research database \& } \\
\text { CISDM database }\end{array}$ & $\begin{array}{l}\text { Number of months since inception of the hedge } \\
\text { fund firm's first fund. For Hedge Fund } \\
\text { Research, we use the variable "inception." } \\
\text { For CISDM we use the variable } \\
\text { "inception_date." }\end{array}$ \\
\hline $\mid \%$ Flow $\mid$ & $\begin{array}{l}\text { Hedge Fund Research database } \& \\
\text { CISDM database }\end{array}$ & $\begin{array}{l}\text { End of quarter AUM less beginning of quarter } \\
\text { AUM }^{*}(1+\text { return }) \text { computed at fund level } \\
\text { and then aggregated across funds for each } \\
\text { hedge fund firm. }\end{array}$ \\
\hline $\begin{array}{l}\text { Northeast } \\
\text { indicator }\end{array}$ & FEC political donor database & $\begin{array}{l}\text { An indicator variable that equals one if the mode } \\
\text { zipcode of hedge fund donors is located in } \\
\text { the northeast (Maine, New Hampshire, } \\
\text { Vermont, Massachusetts, New York, } \\
\text { Connecticut, Rhode Island, Pennsylvania, } \\
\text { New Jersey, Delaware, Maryland, and } \\
\text { Washington DC). The definition of } \\
\text { "northeast" states follows Kostovetsky } \\
\text { (2009). For hedge fund firms without a mode } \\
\text { zipcode (e.g., a hedge fund with only two } \\
\text { donations from different zipcodes), we } \\
\text { investigate the hedge fund via the web to } \\
\text { determine the hedge fund location. }\end{array}$ \\
\hline Manager age & $\begin{array}{l}\text { Main sources: Business week and } \\
\text { LinkedIn } \\
\text { Additional Sources: online media } \\
\text { articles, alumni websites, wedding } \\
\text { announcements, parental eulogies. }\end{array}$ & $\begin{array}{l}\text { Manager's age (divided by 100) in April 2014. If a } \\
\text { manager's age is found in a media article we } \\
\text { assume the age is the reported age plus the } \\
\text { number of years since publication as of } 2014 . \\
\text { For example, if a manager is reported as } 25 \\
\text { years old in an article from } 2004 \text { we record } \\
\text { the age as 35. If no age data is found we } \\
\text { assume the manager was } 22 \text { years old at the } \\
\text { time of their undergraduate graduation. } \\
\text { Finally, in one case the manager died before } \\
\text { 2014. For this observation we record the } \\
\text { manager's age as the age upon the manager's } \\
\text { death. }\end{array}$ \\
\hline
\end{tabular}


Appendix A.

Definitions (continued)

\begin{tabular}{|c|c|c|}
\hline Item & Source & Definition \\
\hline $\begin{array}{l}\text { Manager } \\
\text { gender }\end{array}$ & $\begin{array}{l}\text { Main sources: Business week and } \\
\text { LinkedIn }\end{array}$ & $\begin{array}{l}\text { An indicator variable that equals one for males. } \\
\text { We require a gender specific pronoun or } \\
\text { honorific in any source available. }\end{array}$ \\
\hline $\begin{array}{l}\text { Manager } \\
\text { graduate } \\
\text { degree } \\
\text { indicator }\end{array}$ & $\begin{array}{l}\text { Main sources: Business week and } \\
\text { LinkedIn } \\
\text { Additional sources: online media } \\
\text { articles and alumni websites }\end{array}$ & $\begin{array}{l}\text { An indicator variable that equals one for } \\
\text { managers that have a graduate degree. If we } \\
\text { cannot confirm the manager has a graduate } \\
\text { degree we assume he or she does not. }\end{array}$ \\
\hline $\begin{array}{l}\text { Manager SAT } \\
\text { score }\end{array}$ & $\begin{array}{l}\text { The Integrated Postsecondary } \\
\text { Education Data System Data Center } \\
\text { (IPEDS) } \\
\text { http://nces.ed.gov/ipeds/datacenter/ }\end{array}$ & $\begin{array}{l}\text { The median SAT score at the manager's } \\
\text { undergraduate institution (divided by 100) in } \\
\text { 2005. SAT data is reported separately for the } \\
\text { verbal and quantitative sections. Further, } \\
\text { only the 25th and 75th percentiles are } \\
\text { reported for each section. The median for } \\
\text { each section is defined as the average of the } \\
\text { 25th and 75th percentiles. The median for } \\
\text { the exam is the sum of the median score for } \\
\text { the verbal and quantitative sections. }\end{array}$ \\
\hline $\begin{array}{l}\text { Natural log of } \\
\text { capitalization }\end{array}$ & CRSP & Natural logarithm of security capitalization \\
\hline Age & CRSP & $\begin{array}{l}\text { Number of months the stock has been listed on } \\
\text { CRSP }\end{array}$ \\
\hline $\begin{array}{l}\text { Return } \\
\text { volatility }\end{array}$ & CRSP & $\begin{array}{l}\text { Standard deviation of monthly returns over the } \\
\text { previous year (require at least nine months of } \\
\text { data) }\end{array}$ \\
\hline $\begin{array}{l}\text { Positive } \\
\text { profitability }\end{array}$ & Compustat & $\begin{array}{l}\text { An indicator variable for profitable companies. } \\
\text { Profitable companies are those with positive } \\
\text { net income (the sum of quarterly net income } \\
\text { less quarterly preferred dividends over the } \\
\text { previous four quarters). }\end{array}$ \\
\hline $\begin{array}{l}\text { Dividend } \\
\text { paying }\end{array}$ & Compustat & $\begin{array}{l}\text { An indicator variable for companies that paid a } \\
\text { dividend in the previous year. }\end{array}$ \\
\hline
\end{tabular}




\section{Appendix A.}

Definitions (continued)

\begin{tabular}{|c|c|c|}
\hline Item & Source & Definition \\
\hline $\begin{array}{l}\text { Lottery-type } \\
\text { security }\end{array}$ & CRSP & $\begin{array}{l}\text { An indicator variable for securities with below- } \\
\text { median price, above-median idiosyncratic } \\
\text { volatility, and above-median idiosyncratic } \\
\text { skewness. Following Kumar (2009) and } \\
\text { Kumar, Page, and Spalt (2011), idiosyncratic } \\
\text { volatility is estimated over the previous six } \\
\text { months with a regression of excess daily } \\
\text { returns on a four factor model (excess } \\
\text { market, size, value, and momentum). } \\
\text { Idiosyncratic skewness is estimated over the } \\
\text { previous six months based on a regression of } \\
\text { excess daily returns on a two factor model } \\
\text { (excess market return and squared excess } \\
\text { market return). Idiosyncratic volatility and } \\
\text { idiosyncratic skewness are both calculated } \\
\text { from the residuals of the respective } \\
\text { regressions. }\end{array}$ \\
\hline Turnover & CRSP/13(f) & $\begin{array}{l}\text { Minimum of the dollar value of the hedge fund's } \\
\text { total purchases or sales (as indicated by 13(f) } \\
\text { reports) scaled by the hedge fund's beginning } \\
\text { of quarter long equity portfolio value. }\end{array}$ \\
\hline $\begin{array}{l}\mid \% \text { Change } \\
\text { equity } \\
\text { holdings } \mid\end{array}$ & CRSP/13(f) & $\begin{array}{l}\text { The sum across securities of the end of quarter } \\
\text { number of (split-adjusted) shares held less } \\
\text { the number of beginning of quarter shares } \\
\text { held times beginning of quarter price scaled } \\
\text { by the dollar value of the beginning of } \\
\text { quarter equity portfolio value. }\end{array}$ \\
\hline Enter ratio & CRSP/13(f) & $\begin{array}{l}\text { The numbers of securities hedge fund firm } k \\
\text { enters in a quarter scaled by the number of } \\
\text { securities hedge fund firm } k \text { holds at the end } \\
\text { of the quarter. }\end{array}$ \\
\hline Exit ratio & CRSP/13(f) & $\begin{array}{l}\text { The numbers of securities hedge fund firm } k \\
\text { exits in a quarter scaled by the number of } \\
\text { securities hedge fund firm } k \text { holds at the } \\
\text { beginning of the quarter. }\end{array}$ \\
\hline
\end{tabular}




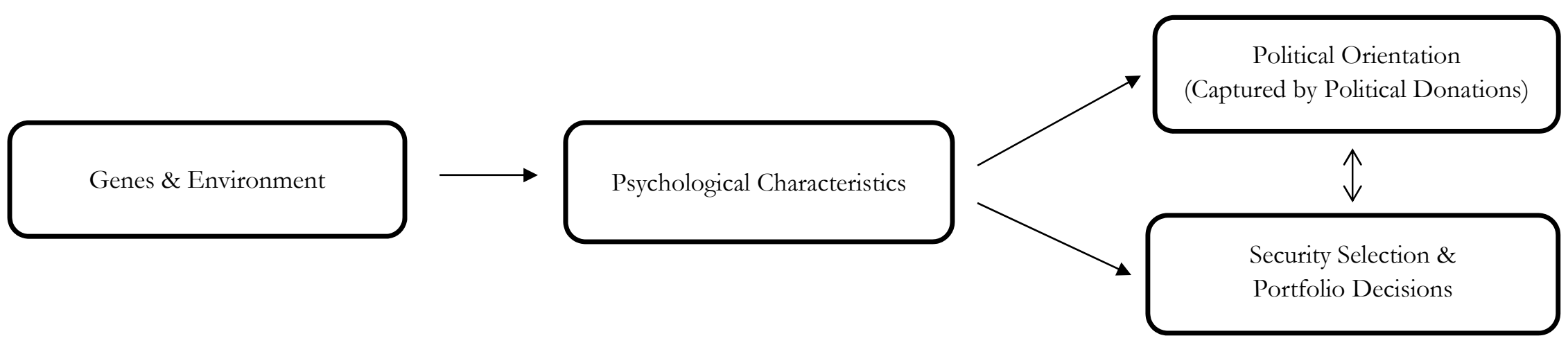

Fig. 1. Research Question Framework

The figure displays how both genes and environment determine psychological characteristics which, in turn, drive both political orientation and security selection and portfolio decisions. 
Table 1

Hedge fund Political Donations Descriptive Statistics

\begin{tabular}{|c|c|c|c|c|}
\hline \multicolumn{5}{|c|}{ Panel A: Time-series descriptive statistics ( $n=52$ quarters, March 2003-December 2012) } \\
\hline & Mean & Median & Minimum & Maximum \\
\hline Number of hedge funds & 201 & 205 & 104 & 302 \\
\hline$\%$ Liberal & $45.30 \%$ & $45.44 \%$ & $41.49 \%$ & $50.95 \%$ \\
\hline$\%$ Conservative & $54.70 \%$ & $54.56 \%$ & $49.05 \%$ & $58.51 \%$ \\
\hline$\%$ Strong Liberal & $34.93 \%$ & $34.85 \%$ & $31.38 \%$ & $39.85 \%$ \\
\hline$\%$ Strong Conservative & $42.97 \%$ & $42.26 \%$ & $36.09 \%$ & $48.03 \%$ \\
\hline$\%$ Strong (either) & $77.90 \%$ & $78.41 \%$ & $73.24 \%$ & $80.69 \%$ \\
\hline Median number of stocks held & 57 & 59 & 46 & 69 \\
\hline Median long-equity port. value & $\$ 405 \mathrm{M}$ & $\$ 405 \mathrm{M}$ & $\$ 200 \mathrm{M}$ & $\$ 661 \mathrm{M}$ \\
\hline \multicolumn{5}{|c|}{ Panel B: Cross-sectional descriptive statistics ( $n=246$ Liberal hedge fund companies) } \\
\hline Number of donations & 23.70 & 7.00 & 1 & 595 \\
\hline Number Republican donations & 5.22 & 1.00 & 0 & 174 \\
\hline Number Democrat donations & 18.48 & 5.00 & 1 & 533 \\
\hline Total Republican donations & $\$ 12,948$ & $\$ 1,450$ & $\$ 0$ & $\$ 787,099$ \\
\hline Total Democrat donations & $\$ 63,439$ & $\$ 8,350$ & $\$ 200$ & $\$ 1,979,707$ \\
\hline \multicolumn{5}{|c|}{ Panel C: Cross-sectional descriptive statistics ( $n=248$ Conservative hedge fund companies) } \\
\hline Number of donations & 25.11 & 5.00 & 1 & 528 \\
\hline Number Republican donations & 16.09 & 4.00 & 1 & 366 \\
\hline Number Democrat donations & 9.02 & 1.00 & 0 & 408 \\
\hline Total Republican donations & $\$ 71,760$ & $\$ 7,333$ & $\$ 500$ & $\$ 2,920,800$ \\
\hline Total Democrat donations & $\$ 22,116$ & $\$ 250$ & $\$ 0$ & $\$ 1,692,148$ \\
\hline
\end{tabular}

The table presents descriptive statistics of 494 hedge fund companies whose managers and employees made political donations over the 1999-2012 sample period. The first row in Panel A reports the timeseries descriptive statistics for the number of hedge funds in the sample each quarter. The next two rows report the time-series descriptive statistics regarding the fraction of hedge fund companies classified as Liberal ( $>50 \%$ of total donations to Democrats) and Conservative $(>50 \%$ of total donations to Republicans). The next three rows report the fraction of hedge funds classified as Strong Liberal ( $>70 \%$ of total donations to Democrats), Strong Conservative ( $>70 \%$ of total donations to Republicans), and strong either ( $>70 \%$ of total donations to one party). The last two rows in Panel A report the time-series descriptive statistics of the cross-sectional median number of stocks held and long-equity portfolio value for hedge funds. Panel B reports cross-sectional descriptive donation statistics for the 246 Liberal hedge funds. Panel C reports analogous statistics for the 248 Conservative hedge funds in our sample. 
Table 2

Descriptive Statistics for Security Characteristics

\begin{tabular}{lrrr}
\hline \multicolumn{4}{c}{ Panel A: Time-series descriptive statistics of mean portfolio characteristics } \\
\hline
\end{tabular}

For each hedge fund quarter observation we compute the weighted characteristics of individual securities held by the fund. Panel A reports the time-series descriptive statistics ( $n=52$ quarters, March 2000-December 2012) of the cross-sectional mean hedge fund portfolio characteristics in our sample. For instance, the cross-sectional average natural logarithm of market capitalization of securities held in hedge fund portfolios averages 22.311 and ranges from 21.828 (in March 2003) to 22.690 (in December 2012). Panel B reports the time-series descriptive statistics of the cross-sectional standard deviation of portfolio characteristics across the hedge funds in our sample. On average, our sample consists of 201 hedge fund companies each quarter (see Table I). Detailed variable definitions are given in Appendix A. 
Table 3

Liberal and Conservative Hedge Funds' Portfolio Characteristics

\begin{tabular}{|c|c|c|c|c|c|c|}
\hline & Liberal & Conservative & $\begin{array}{r}\text { Lib.- Cons. } \\
\text { (t-statistic) }\end{array}$ & "Strong Liberal & $\begin{array}{c}\text { Strong } \\
\text { Conservative }\end{array}$ & $\begin{array}{c}\text { Strong Lib.- } \\
\text { Strong Cons } \\
\text { (t-statistic) }\end{array}$ \\
\hline Natural log capitalization & -0.118 & 0.098 & $\begin{array}{l}-0.216 \\
(-2.27)^{* *}\end{array}$ & -0.150 & 0.061 & $\begin{array}{l}-0.210 \\
(-1.99)^{* *}\end{array}$ \\
\hline Age & -0.132 & 0.110 & $\begin{array}{l}-0.243 \\
(-2.72)^{* * *}\end{array}$ & -0.187 & 0.077 & $\begin{array}{l}-0.265 \\
(-2.69)^{* * *}\end{array}$ \\
\hline Return volatility & 0.067 & -0.056 & $\begin{array}{l}0.123 \\
(1.42)\end{array}$ & 0.137 & -0.046 & $\begin{array}{c}0.183 \\
(1.82)^{*}\end{array}$ \\
\hline Positive profitability & -0.085 & 0.071 & $\begin{array}{l}-0.155 \\
(-1.90)^{*}\end{array}$ & -0.124 & 0.068 & $\begin{array}{l}-0.192 \\
(-1.99)^{* *}\end{array}$ \\
\hline Dividend paying & -0.084 & 0.070 & $\begin{array}{l}-0.155 \\
(-1.61)\end{array}$ & -0.191 & 0.066 & $\begin{array}{l}-0.257 \\
(-2.38)^{* *}\end{array}$ \\
\hline Lottery-type stocks & 0.082 & -0.068 & $\begin{array}{c}0.151 \\
(1.81)^{*}\end{array}$ & 0.130 & -0.054 & $\begin{array}{c}0.184 \\
(1.92)^{*}\end{array}$ \\
\hline Turnover & 0.068 & -0.057 & $\begin{array}{l}0.124 \\
(1.43)\end{array}$ & 0.050 & -0.107 & $\begin{array}{c}0.157 \\
(1.63)\end{array}$ \\
\hline $\mid \%$ Change equity holdings $\mid$ & 0.067 & -0.056 & $\begin{array}{c}0.123 \\
(2.52)^{* *}\end{array}$ & 0.067 & -0.064 & $\begin{array}{c}0.131 \\
(2.45)^{* *}\end{array}$ \\
\hline & \multicolumn{3}{|c|}{$N=10,438$ hedge fund quarter observations } & \multicolumn{3}{|c|}{$N=8,163$ hedge fund quarter observations } \\
\hline
\end{tabular}


Table 3 (Continued)

For each hedge fund-quarter, we compute the weighted mean characteristics for securities held in the hedge fund's portfolio. We also compute portfolio turnover and the absolute percent change in total equity holdings. Each quarter we standardize (rescale to unit variance, zero mean) each portfolio characteristic across all hedge fund firms in our sample. The first three columns report the pooled cross-sectional time-series mean (standardized) characteristics for Liberal ( $>50 \%$ of total donations to Democrats, $n=246$ hedge funds) and Conservative ( $>50 \%$ of total donations to Republicans, $n=248$ hedge funds) hedge funds as well as their differences. The $t$-statistics are based on standard errors clustered at the hedge fund level. The next three columns report analogous statistics for Strong Liberal (at least 70\% of total donations to Democrats, $n=195$ hedge funds) versus Strong Conservative (at least $70 \%$ of total donations to Republicans, $n=210$ hedge funds). The bottom row reports sample sizes. Statistical significance at the $1 \%, 5 \%$, and $10 \%$ level is indicated by ***, **, and *, respectively. 
Table 4

Hedge Fund Entry and Exit Trades

\begin{tabular}{|c|c|c|c|c|c|c|}
\hline & \multicolumn{3}{|c|}{ Entry trades ( $n=52$ quarters) } & \multicolumn{3}{|c|}{ Exit trades ( $n=52$ quarters) } \\
\hline & Strong Liberal & $\begin{array}{c}\text { Strong } \\
\text { Conservative }\end{array}$ & $\begin{array}{l}\text { Strong Lib. - } \\
\text { Strong Cons. } \\
\text { ( } t \text {-statistic) }\end{array}$ & Strong Liberal & $\begin{array}{c}\text { Strong } \\
\text { Conservative }\end{array}$ & $\begin{array}{l}\text { Strong Lib. } \\
\text { Strong Cons } \\
\text { (t-statistic) }\end{array}$ \\
\hline Natural log capitalization & -0.105 & 0.019 & $\begin{array}{l}-0.124 \\
(-4.31)^{* * *}\end{array}$ & -0.100 & 0.016 & $\begin{array}{l}-0.116 \\
(-3.63)^{* * *}\end{array}$ \\
\hline Age & -0.108 & 0.019 & $\begin{array}{l}-0.127 \\
(-7.77)^{* * *}\end{array}$ & -0.102 & 0.021 & $\begin{array}{l}-0.124 \\
(-8.15)^{* * *}\end{array}$ \\
\hline Return volatility & 0.082 & 0.002 & $\begin{array}{l}0.080 \\
(3.84)^{* * *}\end{array}$ & 0.060 & 0.011 & $\begin{array}{c}0.050 \\
(2.11)^{* *}\end{array}$ \\
\hline Positive profitability & -0.084 & 0.029 & $\begin{array}{l}-0.113 \\
(-6.44)^{* * *}\end{array}$ & -0.058 & 0.028 & $\begin{array}{l}-0.086 \\
(-3.97)^{* * *}\end{array}$ \\
\hline Dividend paying & -0.133 & 0.031 & $\begin{array}{c}-0.165 \\
(-10.97)^{* * *}\end{array}$ & -0.120 & 0.021 & $\begin{array}{l}-0.141 \\
(-7.81)^{* * *}\end{array}$ \\
\hline Lottery-type stocks & 0.087 & -0.023 & $\begin{array}{l}0.110 \\
(4.74)^{* * *}\end{array}$ & 0.064 & -0.030 & $\begin{array}{l}0.094 \\
(3.73)^{* * *}\end{array}$ \\
\hline Enter Ratio & 0.028 & -0.090 & $\begin{array}{l}0.118 \\
(7.13)^{* * *}\end{array}$ & & & \\
\hline Exit Ratio & & & & 0.043 & -0.102 & $\begin{array}{l}0.146 \\
(8.16)^{* * *}\end{array}$ \\
\hline
\end{tabular}


Table 4 (Continued)

For each hedge fund-quarter, we compute the value-weighted mean characteristic of stocks the hedge fund enters and exits that quarter. The stock's weight for hedge fund $k$ in quarter $t$ is the value of the entry trade (shares purchased times end of quarter price) scaled by the dollar value of all manager $k$ 's entry trades in quarter $t$. We compute the hedge fund enter ratio as the number of securities fund $k$ enters in quarter $t$ scaled by the number of securities fund $k$ holds at the end of quarter $t$. Each quarter, we standardize (rescale to zero mean, unit variance) portfolio characteristics across all hedge funds in our sample. The first three columns report the time-series mean $(n=52$ quarters) of the cross-sectional average standardized entry trade characteristics for Strong Liberal and Strong Conservative hedge funds, as well as their differences. The associated $t$-statistics are computed from the time-series mean with Newey-West (1987) standard errors. The last three columns report analogous statistics for hedge fund exit trades. The exit ratio is defined as the number of securities fund $k$ completely liquidates in quarter $t$ scaled by the number of securities fund $k$ holds at the beginning of quarter $t$. On average (across time), the median fund makes 19 entry trades and 18 exit trades. Statistical significance at the 1\%,5\%, and 10\% level is indicated by ***, **, and *, respectively. 
Table 5

Portfolio Characteristics - Excluding Large Donors

\begin{tabular}{lccc}
\hline \hline & Strong Liberal & Strong Conservative & $\begin{array}{c}\text { Strong Lib.- Strong } \\
\text { Cons. } \\
(t \text {-statistic })\end{array}$ \\
\hline Natural log capitalization & -0.254 & -0.002 & -0.252 \\
Age & -0.234 & 0.062 & -0.296 \\
Return volatility & 0.227 & & $(-2.76)^{* * *}$ \\
Positive profitability & -0.206 & -0.052 & 0.279 \\
& & 0.067 & $(2.44)^{* *}$ \\
Dividend paying & -0.266 & 0.077 & -0.273 \\
Lottery-type stocks & & & $-2.48)^{* *}$ \\
Turnover & 0.218 & -0.026 & $(-2.79)^{* * *}$ \\
& & & 0.244 \\
| \% Change equity holdings & 0.081 & -0.050 & $(2.21)^{* *}$ \\
& & & 0.131 \\
& 0.074 & -0.040 & $(1.22)$ \\
\hline \hline
\end{tabular}

For each hedge fund-quarter, we compute the weighted mean characteristics for securities held in the hedge fund's portfolio. We also compute portfolio turnover and the absolute percent change in total equity holdings. Each quarter we standardize (rescale to unit variance, zero mean) each portfolio characteristic across all hedge fund managers in our sample. We then limit the sample to funds that give less than $\$ 100,000$ to either party over the entire 1999-2012 period. We report below the pooled cross-sectional time-series mean (standardized) characteristics for Strong Liberal $(>70 \%$ of total donations to Democrats, $n=165$ hedge funds) and Strong Conservative ( $>70 \%$ of total donations to Republicans, $n=191$ hedge funds) hedge funds as well as their differences. The $t$-statistics are based on standard errors clustered at the hedge fund level. The bottom row reports the sample size. Statistical significance at the $1 \%, 5 \%$, and $10 \%$ level is indicated by $* * *, * *$, and $*$, respectively. 
Table 6

Portfolio Characteristics Controlling for Hedge Fund Firm Characteristics

\begin{tabular}{|c|c|c|c|c|c|c|c|c|}
\hline & $\begin{array}{c}\text { Natural log } \\
\text { of } \\
\text { capitalization }\end{array}$ & Age & $\begin{array}{c}\text { Return } \\
\text { volatility }\end{array}$ & $\begin{array}{c}\text { Positive } \\
\text { profitability }\end{array}$ & $\begin{array}{l}\text { Dividend } \\
\text { paying }\end{array}$ & $\begin{array}{l}\text { Lottery-type } \\
\text { stocks }\end{array}$ & Turnover & $\begin{array}{l}\text { \%change } \\
\text { equity } \\
\text { holdings }\end{array}$ \\
\hline Strong Liberal indicator & $\begin{array}{l}-0.356 \\
(-2.47)^{* *}\end{array}$ & $\begin{array}{l}-0.362 \\
(-2.94)^{* * *}\end{array}$ & $\begin{array}{l}0.303 \\
(2.20)^{* *}\end{array}$ & $\begin{array}{l}-0.270 \\
(-1.94)^{*}\end{array}$ & $\begin{array}{l}-0.393 \\
(-2.58)^{* * *}\end{array}$ & $\begin{array}{c}0.320 \\
(2.27)^{* *}\end{array}$ & $\begin{array}{c}0.200 \\
(1.53)\end{array}$ & $\begin{array}{c}0.119 \\
(1.75)^{*}\end{array}$ \\
\hline Leverage dummy & $\begin{array}{l}-0.122 \\
(-0.50)\end{array}$ & $\begin{array}{l}-0.083 \\
(-0.35)\end{array}$ & $\begin{array}{c}0.221 \\
(0.98)\end{array}$ & $\begin{array}{l}-0.076 \\
(-0.38)\end{array}$ & $\begin{array}{l}-0.059 \\
(-0.22)\end{array}$ & $\begin{array}{c}0.021 \\
(0.09)\end{array}$ & $\begin{array}{c}0.234 \\
(1.31)\end{array}$ & $\begin{array}{c}0.090 \\
(0.83)\end{array}$ \\
\hline Lockup dummy & $\begin{array}{l}-0.024 \\
(-0.12)\end{array}$ & $\begin{array}{l}-0.039 \\
(-0.25)\end{array}$ & $\begin{array}{l}-0.078 \\
(-0.44)\end{array}$ & $\begin{array}{c}0.056 \\
(0.30)\end{array}$ & $\begin{array}{l}-0.134 \\
(-0.67)\end{array}$ & $\begin{array}{c}0.007 \\
(0.04)\end{array}$ & $\begin{array}{l}-0.051 \\
(-0.29)\end{array}$ & $\begin{array}{l}-0.007 \\
(-0.10)\end{array}$ \\
\hline Fund age & $\begin{array}{l}-0.246 \\
(-2.19)^{* *}\end{array}$ & $\begin{array}{l}-0.221 \\
(-2.20)^{* *}\end{array}$ & $\begin{array}{c}0.131 \\
(1.23)\end{array}$ & $\begin{array}{l}-0.240 \\
(-2.70)^{* * *}\end{array}$ & $\begin{array}{l}-0.081 \\
(-0.71)\end{array}$ & $\begin{array}{l}0.206 \\
(1.86)^{*}\end{array}$ & $\begin{array}{l}-0.151 \\
(-1.41)\end{array}$ & $\begin{array}{l}-0.178 \\
(-2.78)^{* * *}\end{array}$ \\
\hline Natural log of assets & $\begin{array}{l}0.181 \\
(4.35)^{* * *}\end{array}$ & $\begin{array}{l}0.124 \\
(3.01)^{* * *}\end{array}$ & $\begin{array}{l}-0.050 \\
(-1.38)\end{array}$ & $\begin{array}{l}0.052 \\
(1.61)\end{array}$ & $\begin{array}{l}0.100 \\
(2.54)^{* *}\end{array}$ & $\begin{array}{l}-0.082 \\
(-2.38)^{* *}\end{array}$ & $\begin{array}{l}0.049 \\
(1.23)\end{array}$ & $\begin{array}{c}0.043 \\
(1.83)^{*}\end{array}$ \\
\hline $\mid \%$ flow $\mid$ & $\begin{array}{l}-0.067 \\
(-0.26)\end{array}$ & $\begin{array}{l}-0.010 \\
(-0.04)\end{array}$ & $\begin{array}{l}0.167 \\
(0.60)\end{array}$ & $\begin{array}{c}0.050 \\
(0.19)\end{array}$ & $\begin{array}{l}-0.109 \\
(-0.37)\end{array}$ & $\begin{array}{c}0.044 \\
(0.14)\end{array}$ & $\begin{array}{l}0.910 \\
(3.16)^{* * *}\end{array}$ & $\begin{array}{l}1.311 \\
(5.53)^{* * *}\end{array}$ \\
\hline Northeast dummy & $\begin{array}{c}0.326 \\
(2.11)^{*}\end{array}$ & $\begin{array}{c}0.146 \\
(0.99)\end{array}$ & $\begin{array}{l}-0.176 \\
(-1.17)\end{array}$ & $\begin{array}{c}0.174 \\
(1.19)\end{array}$ & $\begin{array}{l}0.170 \\
(1.05)\end{array}$ & $\begin{array}{l}-0.353 \\
(-2.26)^{* *}\end{array}$ & $\begin{array}{c}0.138 \\
(0.94)\end{array}$ & $\begin{array}{c}0.025 \\
(0.35)\end{array}$ \\
\hline Fund style controls & YES & YES & YES & YES & YES & YES & YES & YES \\
\hline Quarterly fixed effects & YES & YES & YES & YES & YES & YES & YES & YES \\
\hline & \multicolumn{8}{|c|}{$N=3,461$ hedge fund quarter observations } \\
\hline
\end{tabular}


Table 6 (Continued)

For each hedge fund firm-quarter, we compute the weighted mean characteristics for securities held in the hedge fund firm's portfolio. We also compute portfolio turnover and the absolute percent change in total equity holdings. Each quarter we standardize (rescale to unit variance, zero mean) each portfolio characteristic across all hedge fund firms in our sample. We gather hedge fund characteristics from the Hedge Fund Research and Morningstar/CISDM databases. We then limit the sample to hedge fund firms that are classified as Strong Liberal $(>70 \%$ total donations to Democrats, $n=87$ hedge fund firms) or Strong Conservative $(>70 \%$ total donations to Republicans, $n=95$ hedge fund firms) that have fund characteristic data available. We then estimate panel regressions of hedge fund firms' portfolio characteristics on a Strong Liberal indicator variable, an indicator variable for hedge fund firms that use leverage, an indicator variable for hedge fund firms that use lockups, hedge fund firm age, hedge fund firm size (natural log of total fund company AUM), the absolute value of hedge fund firm flows as a percent of beginning of quarter AUM, an indicator variable for hedge fund firms located in the Northeast, indicator variables for hedge fund firm styles, and quarterly fixed effects. The $t$-statistics are based on standard errors clustered at the hedge fund firm level. Statistical significance at the $1 \%, 5 \%$, and $10 \%$ level is indicated by ***, $* *$, and $*$, respectively. 


\section{Table 7}

Portfolio characteristics-Classifications Based on Hedge Fund Manager's Donations Only

\begin{tabular}{lccc}
\hline \hline & Strong Liberal & Strong Conservative & $\begin{array}{c}\text { Strong Lib.- Strong } \\
\text { Cons. } \\
(t \text {-statistic })\end{array}$ \\
\hline Natural log capitalization & & & -0.275 \\
Age & -0.123 & 0.153 & $-2.59)^{* * *}$ \\
Return volatility & -0.130 & 0.144 & -0.275 \\
& & & $-2.57)^{* * *}$ \\
Positive profitability & 0.079 & -0.124 & 0.202 \\
& & & $(1.96)^{* *}$ \\
Dividend paying & -0.074 & 0.103 & -0.177 \\
& & & $-1.86)^{*}$ \\
Lottery-type stocks & -0.111 & 0.132 & -0.244 \\
& & & $-2.22)^{* *}$ \\
Turnover & 0.088 & -0.089 & 0.177 \\
& & & $(1.81)^{*}$ \\
| \% Change equity holdings & 0.047 & -0.135 & 0.182 \\
& & & $(1.83)^{*}$ \\
& 0.059 & -0.097 & 0.157 \\
& & & $(2.64)^{* * *}$
\end{tabular}

$N=7,658$ hedge fund quarter observations

For each hedge fund-quarter, we compute the weighted mean characteristics for securities held in the hedge fund's portfolio. We also compute portfolio turnover and the absolute percent change in total equity holdings. Each quarter we standardize (rescale to unit variance, zero mean) each portfolio characteristic across all hedge fund firms in our sample. We then limit the sample to hedge funds where the hedge fund manager is the largest donor and the manager is classified as a Strong Liberal ( $>70 \%$ total donations to Democrats, $n=176$ hedge fund managers) or a Strong Conservative ( $>70 \%$ total donations to Republicans, $n=197$ hedge fund managers). We report below the pooled crosssectional time-series mean (standardized) characteristics for Strong Liberal and Strong Conservative hedge funds as well as their differences. The $t$-statistics are based on standard errors clustered at the hedge fund level. The bottom row reports the sample size. Statistical significance at the 1\%, 5\%, and $10 \%$ level is indicated by $* * *, * *$, and $*$, respectively. 
Table 8

Portfolio Characteristics Controlling for Manager Characteristics

\begin{tabular}{|c|c|c|c|c|c|c|c|c|}
\hline & $\begin{array}{c}\text { Natural log } \\
\text { of } \\
\text { capitalization }\end{array}$ & Age & $\begin{array}{c}\text { Return } \\
\text { volatility }\end{array}$ & $\begin{array}{c}\text { Positive } \\
\text { profitability }\end{array}$ & $\begin{array}{l}\text { Dividend } \\
\text { paying }\end{array}$ & $\begin{array}{c}\text { Lottery-type } \\
\text { stocks }\end{array}$ & Turnover & $\begin{array}{c}\% \text { Change } \\
\text { equity } \\
\text { holdings }\end{array}$ \\
\hline Strong Liberal indicator & $\begin{array}{l}-0.412 \\
(-3.22)^{* * *}\end{array}$ & $\begin{array}{l}-0.286 \\
(-2.40)^{* *}\end{array}$ & $\begin{array}{c}0.315 \\
(2.45)^{* *}\end{array}$ & $\begin{array}{l}-0.33 \\
(-2.96)^{* * *}\end{array}$ & $\begin{array}{l}-0.329 \\
(-2.48)^{* *}\end{array}$ & $\begin{array}{l}0.354 \\
(2.84)^{* * *}\end{array}$ & $\begin{array}{l}0.133 \\
(1.24)\end{array}$ & $\begin{array}{c}0.114 \\
(1.83)^{*}\end{array}$ \\
\hline Manage age & $\begin{array}{l}-0.618 \\
(-0.91)\end{array}$ & $\begin{array}{l}0.063 \\
(0.10)\end{array}$ & $\begin{array}{l}-0.292 \\
(-0.44)\end{array}$ & $\begin{array}{c}0.019 \\
(0.03)\end{array}$ & $\begin{array}{l}-0.076 \\
(-0.11)\end{array}$ & $\begin{array}{c}0.472 \\
(0.68)\end{array}$ & $\begin{array}{l}-1.87 \\
(-4.18) * * *\end{array}$ & $\begin{array}{l}-1.213 \\
(-4.13)^{* * *}\end{array}$ \\
\hline Gender & $\begin{array}{l}-0.108 \\
(-0.31)\end{array}$ & $\begin{array}{l}-0.096 \\
(-0.25)\end{array}$ & $\begin{array}{l}0.013 \\
(0.05)\end{array}$ & $\begin{array}{c}0.056 \\
(0.17)\end{array}$ & $\begin{array}{c}0.016 \\
(0.04)\end{array}$ & $\begin{array}{c}0.019 \\
(0.09)\end{array}$ & $\begin{array}{c}0.184 \\
(0.80)\end{array}$ & $\begin{array}{l}0.104 \\
(0.76)\end{array}$ \\
\hline Graduate degree & $\begin{array}{l}-0.003 \\
(-0.02)\end{array}$ & $\begin{array}{l}-0.179 \\
(-1.35)\end{array}$ & $\begin{array}{l}0.141 \\
(1.15)\end{array}$ & $\begin{array}{l}-0.085 \\
(-0.76)\end{array}$ & $\begin{array}{l}-0.090 \\
(-0.70)\end{array}$ & $\begin{array}{c}0.039 \\
(0.35)\end{array}$ & $\begin{array}{l}0.126 \\
(1.15)\end{array}$ & $\begin{array}{l}0.112 \\
(1.63)\end{array}$ \\
\hline Median SAT & $\begin{array}{l}-0.003 \\
(-0.07)\end{array}$ & $\begin{array}{l}-0.111 \\
(-2.12)^{* *}\end{array}$ & $\begin{array}{c}0.012 \\
(0.21)\end{array}$ & $\begin{array}{c}0.054 \\
(1.12)\end{array}$ & $\begin{array}{l}-0.058 \\
(-1.13)\end{array}$ & $\begin{array}{l}-0.061 \\
(-1.19)\end{array}$ & $\begin{array}{l}0.025 \\
(0.65)\end{array}$ & $\begin{array}{c}0.001 \\
(0.03)\end{array}$ \\
\hline Quarterly fixed effects & YES & YES & YES & YES & YES & YES & YES & YES \\
\hline
\end{tabular}

For each hedge fund-quarter, we compute the weighted mean characteristics for securities held in the hedge fund's portfolio. We also compute portfolio turnover and the absolute percent change in total equity holdings. Each quarter we standardize (rescale to unit variance, zero mean) each portfolio characteristic across all hedge fund firms in our sample. We then limit the sample to hedge funds where: (1) the hedge fund manager is the largest donor, (2) we are able to collect the hedge fund manager's personal data (e.g., age), and (3) the manager is classified as a Strong Liberal ( $>70 \%$ total donations to Democrats, $n=143$ hedge fund managers) or a Strong Conservative $(>70 \%$ of the manager's donations to Republicans, $n=152$ hedge fund managers). We then estimate panel regressions of hedge fund firms' portfolio characteristics on a Strong Liberal indicator variable, manager age, manager gender, an indicator for whether the manager has earned a graduate degree, the median SAT score for the manager's undergraduate institution, and quarterly fixed effects. The $t$-statistics are based on standard errors clustered at the hedge fund firm level. Statistical significance at the $1 \%, 5 \%$, and $10 \%$ level is indicated by $* * *, * *$, and $*$, respectively. 
Table 9

Portfolio Characteristics Controlling for Hedge Fund and Manager Characteristics

\begin{tabular}{|c|c|c|c|c|c|c|c|c|}
\hline & $\begin{array}{c}\text { Natural log } \\
\text { of } \\
\text { capitalization }\end{array}$ & Age & $\begin{array}{c}\text { Return } \\
\text { volatility }\end{array}$ & $\begin{array}{c}\text { Positive } \\
\text { profitability }\end{array}$ & $\begin{array}{c}\text { Dividend } \\
\text { paying }\end{array}$ & $\begin{array}{c}\text { Lottery-type } \\
\text { stocks }\end{array}$ & Turnover & $\begin{array}{c}\% \text { Change } \\
\text { equity } \\
\text { holdings }\end{array}$ \\
\hline Strong Liberal indicator & $\begin{array}{l}-0.539 \\
(-3.65) * * *\end{array}$ & $\begin{array}{l}-0.297 \\
(-2.10)^{* *}\end{array}$ & $\begin{array}{c}0.514 \\
(3.24)^{* * *}\end{array}$ & $\begin{array}{l}-0.509 \\
(-3.47)^{* * *}\end{array}$ & $\begin{array}{l}-0.524 \\
(-3.01)^{* * *}\end{array}$ & $\begin{array}{l}0.435 \\
(2.81)^{* * *}\end{array}$ & $\begin{array}{c}0.312 \\
(2.05)^{* *}\end{array}$ & $\begin{array}{c}0.180 \\
(2.22)^{* *}\end{array}$ \\
\hline Manager age & $\begin{array}{c}0.058 \\
(0.07)\end{array}$ & $\begin{array}{c}0.978 \\
(1.12)\end{array}$ & $\begin{array}{c}-1.171 \\
(-1.69)^{*}\end{array}$ & $\begin{array}{c}1.240 \\
(1.53)\end{array}$ & $\begin{array}{c}0.679 \\
(0.68)\end{array}$ & $\begin{array}{c}-0.804 \\
(-1.28)\end{array}$ & $\begin{array}{l}-2.48 \\
(-3.60)^{* * *}\end{array}$ & $\begin{array}{l}-1.376 \\
(-3.74)^{* * *}\end{array}$ \\
\hline Gender & $\begin{array}{c}0.235 \\
(0.59)\end{array}$ & $\begin{array}{c}0.497 \\
(1.66)^{*}\end{array}$ & $\begin{array}{c}-0.301 \\
(-0.99)\end{array}$ & $\begin{array}{c}0.275 \\
(0.53)\end{array}$ & $\begin{array}{c}0.344 \\
(1.06)\end{array}$ & $\begin{array}{l}-0.133 \\
(-0.43)\end{array}$ & $\begin{array}{c}0.390 \\
(1.38)\end{array}$ & $\begin{array}{c}0.174 \\
(1.25)\end{array}$ \\
\hline Graduate degree & $\begin{array}{l}0.033 \\
(0.23)\end{array}$ & $\begin{array}{c}0.083 \\
(0.63)\end{array}$ & $\begin{array}{c}0.045 \\
(0.30)\end{array}$ & $\begin{array}{l}-0.072 \\
(-0.49)\end{array}$ & $\begin{array}{c}0.098 \\
(0.54)\end{array}$ & $\begin{array}{c}0.019 \\
(0.14)\end{array}$ & $\begin{array}{c}0.151 \\
(1.10)\end{array}$ & $\begin{array}{l}0.065 \\
(0.74)\end{array}$ \\
\hline Median SAT & $\begin{array}{l}-0.017 \\
(-0.28)\end{array}$ & $\begin{array}{l}-0.030 \\
(-0.58)\end{array}$ & $\begin{array}{l}-0.045 \\
(-0.83)\end{array}$ & $\begin{array}{c}0.086 \\
(1.59)\end{array}$ & $\begin{array}{c}0.007 \\
(0.10)\end{array}$ & $\begin{array}{l}-0.054 \\
(0.88)\end{array}$ & $\begin{array}{c}0.025 \\
(0.47)\end{array}$ & $\begin{array}{l}-0.018 \\
(-0.66)\end{array}$ \\
\hline Leverage dummy & $\begin{array}{l}-0.314 \\
(-1.08)\end{array}$ & $\begin{array}{l}-0.086 \\
(-0.29)\end{array}$ & $\begin{array}{c}0.122 \\
(0.44)\end{array}$ & $\begin{array}{c}0.042 \\
(0.19)\end{array}$ & $\begin{array}{c}0.020 \\
(0.06)\end{array}$ & $\begin{array}{l}-0.038 \\
(-0.14)\end{array}$ & $\begin{array}{l}-0.054 \\
(-0.27)\end{array}$ & $\begin{array}{l}-0.013 \\
(-0.11)\end{array}$ \\
\hline Lockup dummy & $\begin{array}{c}0.125 \\
(0.55)\end{array}$ & $\begin{array}{c}0.022 \\
(0.13)\end{array}$ & $\begin{array}{l}-0.176 \\
(-0.95)\end{array}$ & $\begin{array}{c}-0.071 \\
(-0.39)\end{array}$ & $\begin{array}{c}-0.189 \\
(-0.88)\end{array}$ & $\begin{array}{c}0.060 \\
(0.31)\end{array}$ & $\begin{array}{l}-0.083 \\
(-0.45)\end{array}$ & $\begin{array}{c}0.094 \\
(0.97)\end{array}$ \\
\hline Fund age & $\begin{array}{l}-0.075 \\
(-0.65)\end{array}$ & $\begin{array}{c}-0.273 \\
(-2.12)^{* *}\end{array}$ & $\begin{array}{c}0.175 \\
(1.41)\end{array}$ & $\begin{array}{c}-0.229 \\
(-1.81)^{*}\end{array}$ & $\begin{array}{c}-0.173 \\
(-1.32)\end{array}$ & $\begin{array}{c}0.179 \\
(1.42)\end{array}$ & $\begin{array}{c}0.125 \\
(1.08)\end{array}$ & $\begin{array}{c}-0.144 \\
(-2.20)^{* *}\end{array}$ \\
\hline Natural log of assets & $\begin{array}{c}0.102 \\
(2.16)^{* *}\end{array}$ & $\begin{array}{c}0.001 \\
(0.00)\end{array}$ & $\begin{array}{c}0.024 \\
(0.54)\end{array}$ & $\begin{array}{c}0.000 \\
(0.01)\end{array}$ & $\begin{array}{c}-0.012 \\
(-0.22)\end{array}$ & $\begin{array}{l}-0.044 \\
(-1.06)\end{array}$ & $\begin{array}{c}0.025 \\
(0.56)\end{array}$ & $\begin{array}{c}0.040 \\
(1.39)\end{array}$ \\
\hline $\mid \%$ flow $\mid$ & $\begin{array}{c}0.085 \\
(0.33)\end{array}$ & $\begin{array}{c}0.059 \\
(0.24)\end{array}$ & $\begin{array}{c}0.263 \\
(0.89)\end{array}$ & $\begin{array}{l}-0.020 \\
(-0.16)\end{array}$ & $\begin{array}{l}-0.105 \\
(-0.33)\end{array}$ & $\begin{array}{c}-0.085 \\
(-0.29)\end{array}$ & $\begin{array}{c}0.765 \\
(2.40)^{* *}\end{array}$ & $\begin{array}{c}1.275 \\
(4.57) * * *\end{array}$ \\
\hline Northeast dummy & $\begin{array}{c}0.165 \\
(1.10)\end{array}$ & $\begin{array}{c}0.030 \\
(0.19)\end{array}$ & $\begin{array}{l}-0.160 \\
(-1.00)\end{array}$ & $\begin{array}{c}0.134 \\
(0.94)\end{array}$ & $\begin{array}{c}0.248 \\
(1.42)\end{array}$ & $\begin{array}{c}-0.260 \\
(-1.61)\end{array}$ & $\begin{array}{c}0.243 \\
(1.36)\end{array}$ & $\begin{array}{c}0.129 \\
(1.62)\end{array}$ \\
\hline Fund style controls & YES & YES & YES & YES & YES & YES & YES & YES \\
\hline Quarterly fixed effects & YES & YES & YES & YES & YES & YES & YES & YES \\
\hline & \multicolumn{8}{|c|}{$N=2,574$ hedge fund quarter observations } \\
\hline
\end{tabular}


TABLE 9 (CONTINUED)

For each hedge fund firm-quarter, we compute the weighted mean characteristics for securities held in the hedge fund firm's portfolio. We also compute portfolio turnover and the absolute percent change in total equity holdings. Each quarter we standardize (rescale to unit variance, zero mean) each portfolio characteristic across all hedge fund firms in our sample. We then limit the sample to hedge fund firms where: (1) the hedge fund manager is the largest donor, (2) we are able to collect the hedge fund manager's personal data (e.g., age), (3) we have hedge fund characteristic data (from Hedge Fund Research or Morningstar/CISDM databases), and (4) the manager is classified as a Strong Liberal ( $>70 \%$ total donations to Democrats, $n=61$ hedge fund managers) or a Strong Conservative ( $>70 \%$ of the manager's donations to Republicans, $n=70$ hedge fund managers). We then estimate panel regressions of hedge fund firms' portfolio characteristics on a Strong Liberal indicator variable, manager characteristics (see Table 8), hedge fund firm characteristics (see Table 6), and quarterly fixed effects. The $t$-statistics are based on standard errors clustered at the hedge fund firm level. Statistical significance at the 1\%, $5 \%$, and $10 \%$ level is indicated by $* * *, * *$, and $*$, respectively. 